\title{
THE EFFECT OF STEAM OXIDATION ON THE STRENGTH AND ELASTIC MODULUS OF GRAPHITE H-451
}

by

C. VELASQUEZ, W. JOHNSON, G. HIGHTOWER, and R. BURNETTE

Prepared under

Contract EY-76-C-03-0167

Project Agreement No. 17

for the San Francisco Operations Office

Department of Energy 


\section{DISCLAIMER}

This report was prepared as an account of work sponsored by an agency of the United States Government. Neither the United States Government nor any agency Thereof, nor any of their employees, makes any warranty, express or implied, or assumes any legal liability or responsibility for the accuracy, completeness, or usefulness of any information, apparatus, product, or process disclosed, or represents that its use would not infringe privately owned rights. Reference herein to any specific commercial product, process, or service by trade name, trademark, manufacturer, or otherwise does not necessarily constitute or imply its endorsement, recommendation, or favoring by the United States Government or any agency thereof. The views and opinions of authors expressed herein do not necessarily state or reflect those of the United States Government or any agency thereof. 


\section{DISCLAIMER}

Portions of this document may be illegible in electronic image products. Images are produced from the best available original document. 
This report was prepared as an account of work sponsored by the United States Government Neither the United States nor the Department of Energy, nor any of their employees, nor any of their contractors, subcontractors, or their employees, makes any warranty, express or impled, or assumes any legal liability or responsibility for the accuracy, completeness or usefulness of any information, apparatus, product or process disclosed, or represents that its use would not infringe privately owned rights

\author{
Printed in the United States of America \\ Available from \\ National Technical Information Service \\ U.S. Department of Commerce \\ 5285 Port Royal Road \\ Springfield, Virginia 22161 \\ Price: Printed Copy $\$ 4.50$; Microfiche $\$ 3.00$
}




\title{
THE EFFECT OF STEAM OXIDATION ON THE STRENGTH AND ELASTIC MODULUS OF GRAPHITE H-451
}

\author{
by \\ C. VELASQUEZ, W. JOHNSON, G. HIGHTOWER, \\ and R. BURNETTE
}

Prepared under This report was prepared as an account of work
sponsored by the United States Government Netther the
United States nor the United States Department of
Energy, nor any of their employees, nor any of their
contractors, subcontractors, or their employees, makes
any warranty, express or implied, or assumes any legal
lability or responsiblity for the accuracy, completeness
or usefulness of any information, apparatus, product or
process disclosed, or represents that its use would not
infrunge prvately owned nghts Contract EY-76-C-03-0167

Project Agreement No. 17 for the San Francisco Operations Office Department of Energy

GENERAL ATOMIC PROJECT 3224

DATE PUBLISHED: DECEMBER 1977

UISTRIBUTLON QE IHUS DOCUMENT IS UNLHKITED

\section{GENERAL ATOMIC COMPANY}


ABSTRACT

Graphite grade $\mathrm{H}-451$, the reference material used as fuel and reflector elments in General Atomic large high-temperature gas-cooled reactors, was oxidized to $20 \%$ burnoff by weight in steam-helium mixtures, and the effects of oxidation on ultimate tensile strength (UTS) and elastic modulus (E) were studied. Large numbers of small cylindrical samples cored from selected locations in a $\log$ of preproduction $\mathrm{H}-451$ graphite were oxidized at 1073 and $1273 \mathrm{~K}\left(1472^{\circ}\right.$ and $\left.1832^{\circ} \mathrm{F}\right)$ in helium containing $3 \%$ water vapor and $5 \% \mathrm{H}_{2}$. The UTS and $E$ of oxidized specimens were measured and the results compared with those for nonoxidized control specimens. The average rate of change of UTS and $\mathrm{E}$ with burnoff at $1273 \mathrm{~K}\left(1832^{\circ} \mathrm{F}\right)$ (up to $20 \%$ burnoff) averaged $3.6 \%$ and $5.2 \%$, respectively. Statistical analysis (comparison of population means) of the low burnoff strength data showed no significant differences between the nonoxidized control and oxidized specimens at burnoffs of up to approximately $2 \%$. 
CONTENTS

ABSTRACT . . . . . . . . . . . . . . . . . . . . . 1 . 11

1. INTRODUCTION . . . . . . . . . . . . . . . . . 1

2. EXPERIMENTAL PROCEDURES .................... . . . . 3

2.1. Sampling and Specimen Preparation . . . . . . . . . 3

2.2. Strength, Elastic Modulus, and Strain at Fracture

Measurements . . . . . . . . . . . . . . . . . . 11

3. EXPERIMENTAL RESULTS . . . . . . . . . . . . . . . . 12

3.1. Ultimate Tensile Strength and Elastic Modulus . . . . . . 12

3.2. Strain at Fracture . . . . . . . . . . . . . . 25

3.3. Oxidation-Induced Bulk Density Profiles . . . . . . . 25

4. CONCLUSIONS . . . . . . . . . . . . . . . . . 32

ACKNOWLEDGMENTS . . . . . . . . . . . . . . . . . . . . 34

REFERENCES . . . . . . . . . . . . . . . . . . . 35

APPENDIX: TENSILE PROPERTIES OF H-451 GRAPHITE: LOG NO. 6484-34. . . A-1

\section{FIGURES}

1. Sampling plan of graphite log showing material (slab) designated for oxidation tests ................... 4

2. Slab sectioning .. . . . . . . . . . . . . . . . 5

3. Sampling diagram of $\mathrm{slab} 5 \mathrm{~A} / 5 \mathrm{~B}$ : center section . . . . . . . 6

4. Sampling diagram of slab 5A/5B: edge section . . . . . . . 7

5. Steam-graphite oxidation apparatus . . . . . . . . . . . 10

6. Tensile strength versus burnoff for $\mathrm{H}-451$ graphite ( $\log 6484-34$ ) oxidized at $1073 \mathrm{~K}\left(1472^{\circ} \mathrm{F}\right)$ : quarter-length axial edge and center specimens .........................

7. Tensile strength versus burnoff for H-451 graphite (log 6484-34) oxidized at $1273 \mathrm{~K}\left(1832^{\circ} \mathrm{F}\right)$ : quarter-length axial edge and center specimens . . . . . . . . . . . . . . . . . . . . .

8. Tensile strength versus burnoff of $\mathrm{H}-451$ graphite ( $\log 6484-34)$ : quarter-length axial center specimens . . . . . . . . . . . 
9. Tensile strength versus burnoff for H-451 graphite (log 6484-34) oxidized at $1073 \mathrm{~K}\left(1472^{\circ} \mathrm{F}\right)$ : quarter-length radial specimens . . 16

10. Tensile strength versus burnoff for H-451 graphite ( $\log 6484-34$ ) oxidized at $1273 \mathrm{~K}\left(1832^{\circ} \mathrm{F}\right)$ : quarter-length radial specimens . . 17

11. Elastic modulus versus burnoff for H-451 graphite ( $\log 6484-34$ ): quarter-length axial center specimens . . . . . . . . . 18

12. Elastic modulus versus burnoff for H-451 graphite ( $\log 6484-34$ ) oxidized at $1273 \mathrm{~K}\left(1832^{\circ} \mathrm{F}\right)$ : quarter-length axial specimens . . . 19

13. Elastic modulus versus burnoff for H-451 graphite ( $\log 6484-34$ ) oxidized at $1273 \mathrm{~K}\left(1832^{\circ} \mathrm{F}\right)$ : quarter-length radial edge specimens . . . . . . . . . . . . . . . . . . . . . 20

14. Bulk density profile of H-451 graphite: $0 \%$ burnoff . . . . . . . 27

15. Bulk density profile of $\mathrm{H}-451$ graphite (sample 6484-34-5B): quarter-length axial center specimen oxidized at $1073 \mathrm{~K}\left(1472^{\circ} \mathrm{F}\right)$ to $0.96 \%$ burnoff .....................

16. Bulk density profile of $\mathrm{H}-451$ graphite (sample 6484-34-5B): quarter-length axial center specimen oxidized at $1273 \mathrm{~K}\left(1832^{\circ} \mathrm{F}\right)$ to $4.3 \%$ burnoff ......................

17. Bulk density profile of $\mathrm{H}-451$ graphite (sample 6484-34-5A-29B): quarter-length axial center specimen oxidized at $1273 \mathrm{~K}\left(1832^{\circ} \mathrm{F}\right)$ to $1.5 \%$ burnoff . . . . . . . . . . . . . . . . . . .

TABLES

1. Allocation of graphite samples for oxidation studies . . . . . . 8

2. Mean ultimate tensile strength and mean elastic modulus for nonoxidized control specimens . . . . . . . . . . . . . .

3. Summary of mechanical properties and comparison of population means for quarter-length samples from H-451 . . . . . . . . . . 22

4. Reduction in ultimate tensile strength and elastic modulus with oxidation . . . . . . . . . . . . . . . . . . 23

5. Effect of oxidation on strain at fracture . . . . . . . . . . 26 


\section{INTRODUCTION}

Graphite oxidation in a high-temperature gas-cooled reactor (HTGR) may occur because of two distinct types of steam ingress: (1) a major steam leak caused by, for example, rupture of a heat exchanger steam tube and (2) continuous low-level in-leakage. The degree of oxidation due to the first type of leak would be negligible because the reactor would be shut down within seconds of such an event (Ref. 1). A continuous low-level type of leak is of more concern because such a leak is permitted under the proposed technical specifications for normal full-power operation. This type of leak could result in moisture concentrations in the range 1 to 10 $\mathrm{Pa}$ (10 to $100 \mathrm{\mu atm}$ ) over the $40-\mathrm{yr}$ life of the reactor graphite components. Low levels of steam for long periods of time could lead to small but measurable oxidation of the core graphite.

The fuel element blocks are subject to mechanical stresses including compressive stresses (i.e., those due to the weight of the core components) and tensile stresses (those due to irradiation and thermal gradient effects). The fuel element blocks may have to withstand additional stresses resulting from seismic events. Because of these in-service requirements, it is essential that the blocks retain their structural integrity. Consequently, the effect of oxidation on the ultimate tensile strength (UTS) and elastic modulus (E) was determined.

The purpose of this report is to characterize H-451 graphite, * the reference material for fuel and replaceable reflectors in the General Atomic (GA) large high-temperature gas-cooled reactor (LHTGR), by determining the effect of uniform oxidation on UTS and $E$. The oxidation experiments were

* Great Lakes Carbon Company Grade H-451 is commercially manufactured by extrusion with petroleum-based near-isotropic cokes. A description of Grade H-451, its properties, and impurity content is given in Ref. 2 . 
performed in steam-helium mixtures using small specimens taken from one axial location in a single preproduction log (GA log 6384-34). Control specimens taken from the same population as those used for the oxidation experiments were used to determine changes in UTS and $E$. 


\section{EXPERIMENTAL PROCEDURES}

The experimental work consisted of uniform and isothermal oxidation of large numbers of small test specimens at 1073 and $1273 \mathrm{~K}\left(1472^{\circ}\right.$ and $\left.1832^{\circ} \mathrm{F}\right)$ in steam-helium mixtures and subsequent measurement of the UTS and $E$ of the oxidized specimens. In a few cases, strain at fracture was determined. The UTS and $E$ values of the oxidized specimens were compared with those of the nonoxidized control specimens, which were taken from the same population as the specimens utilized for oxidation, to determine the changes caused by burnoff.

\subsection{SAMPLING AND SPECIMEN PREPARATION}

Commercial graphite logs of the size used for fuel and reflector elements in HTGRs [0.43-m (17-in.) diameter, 0.86-m (34-in.) length] have been shown to have a nonuniform distribution of properties within a single $\log$ (Ref. 2) It has been observed, for example, that the UTS and $E$ of H-451 graphite are highest in the axial direction (parallel to extrusion), lowest at the midlength center (MLC) of a $10 \mathrm{~g}$, and increase from the center to the edges. (Ref. 2) Specimens were selected from quarter-length center (QLC) and quarter-length edge (QLE) positions of a GA $10 g$ 6384-34 to obtain data on material of highest and lowest strength. Axial and radial specimens were selected as indicated in Figs. 1 through 4. Specimen cores with diameters of $7.93 \mathrm{~mm}(0.3125 \mathrm{in.})$ and lengths of $63.4 \mathrm{~mm}(2.5 \mathrm{in.})$ were removed from each section (Figs. 3,4), and the cores were machined by centerless grinding into specimens with diameters of $6.34 \mathrm{~mm}$ (0.25 in.). Groups of samples were randomized and allocated for oxidation according to Table 1. The specimens were oxidized in 63.4-mm (2.5-in.) lengths. After oxidation, approximately $0.6 \mathrm{~mm}$ (0.25 in.) was removed from each end of each oxidized specimen, and each specimen was cut in half to provide two specimens $6.34 \mathrm{~mm}(0.25 \mathrm{in.})$ in diameter and $23 \mathrm{~mm}(0.9 \mathrm{in.})$ in length. 


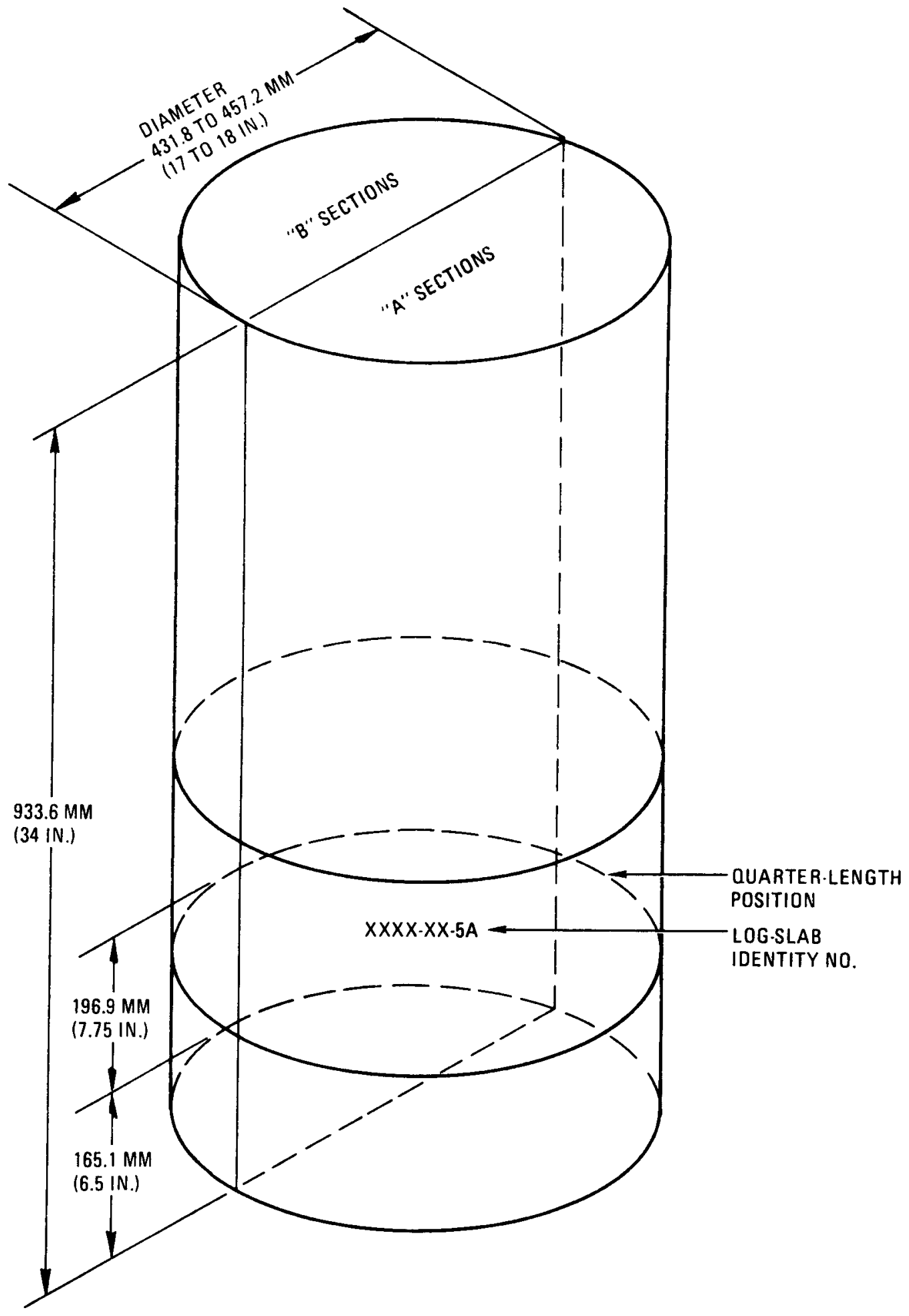

Fig. 1. Sampling plan of graphite log showing material (slab) designated for oxidation tests 


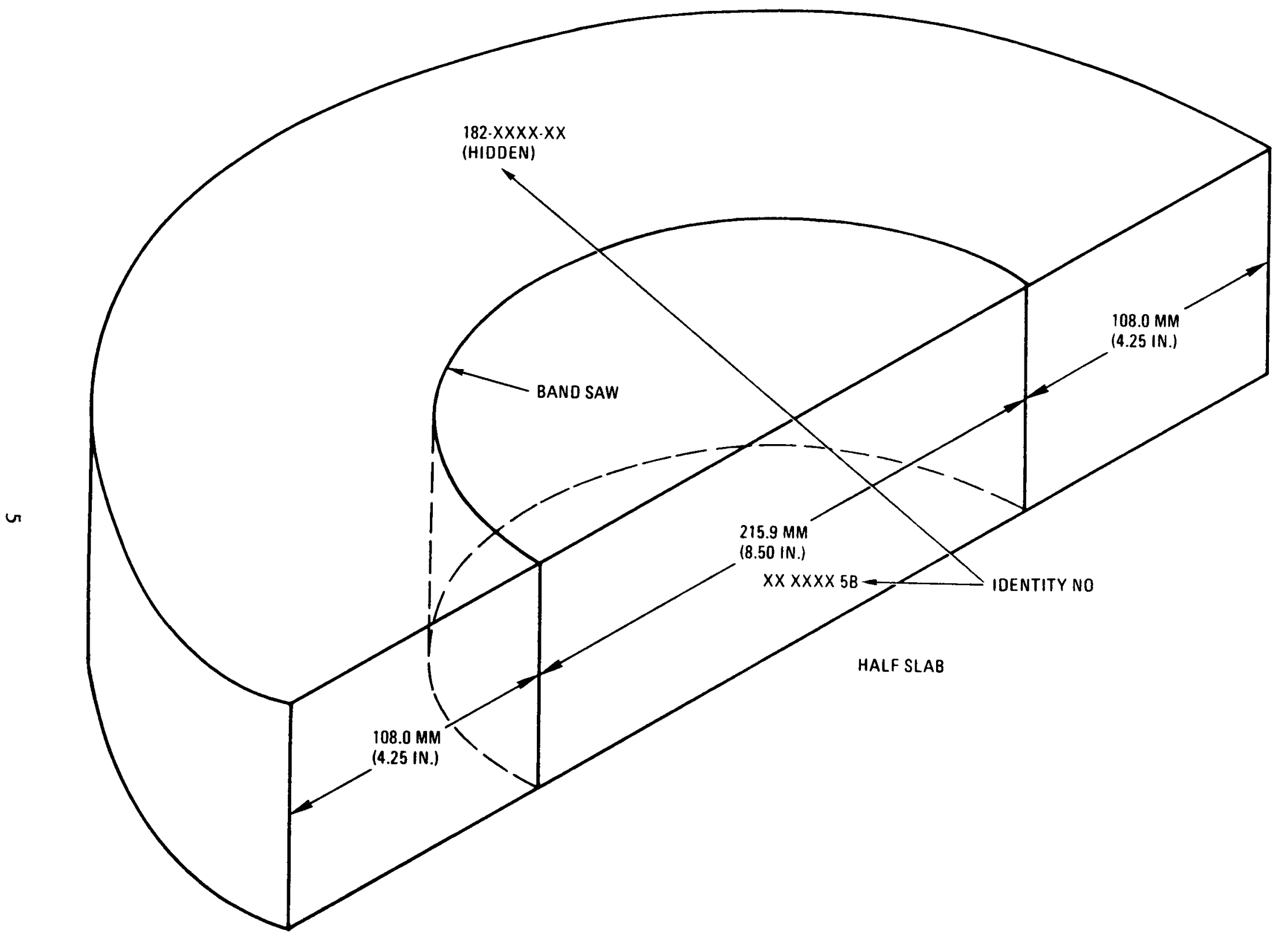

Fig. 2. Slab sectioning 

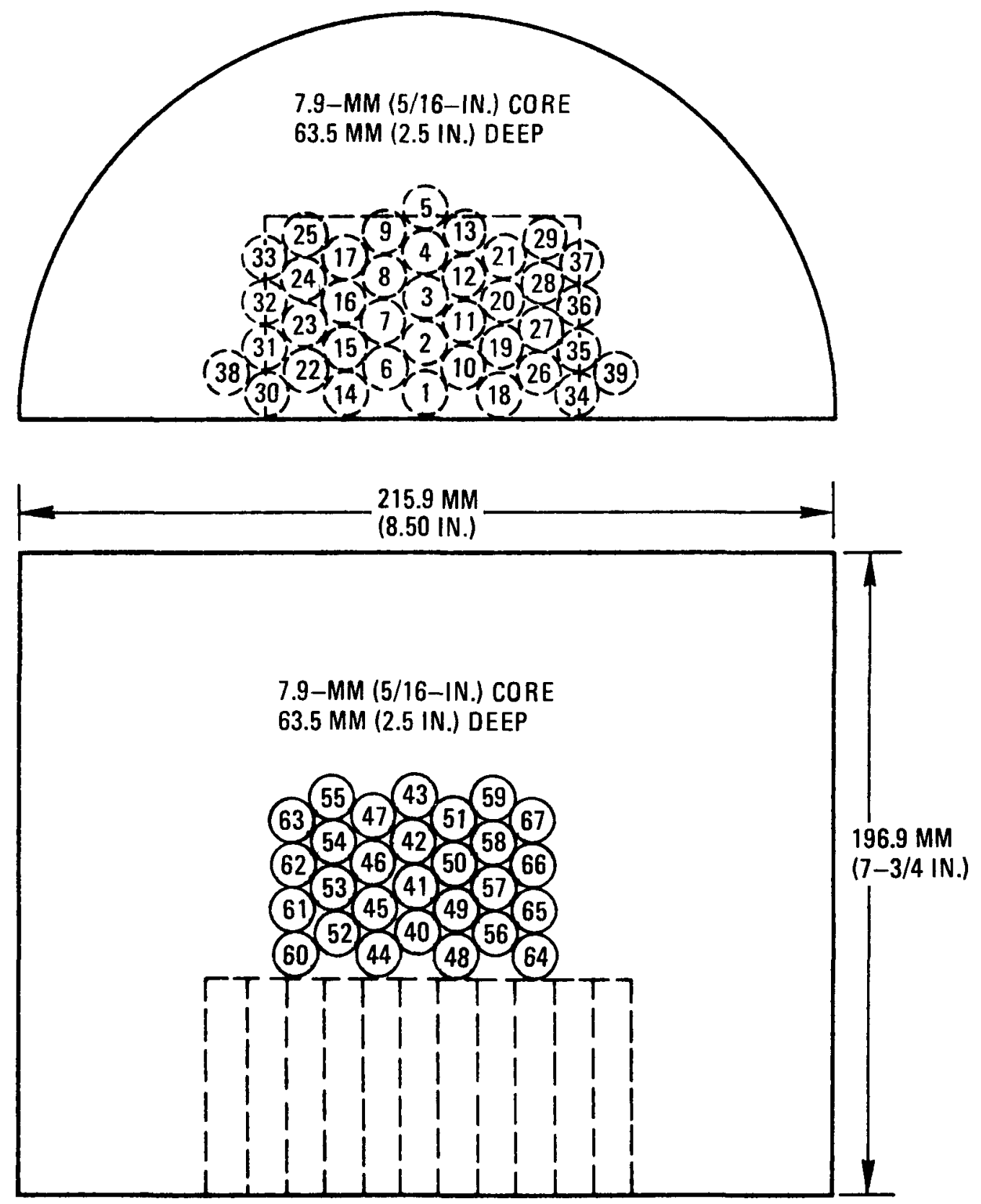

Fig. 3. Sampling diagram of slab 5A/5B: center section 


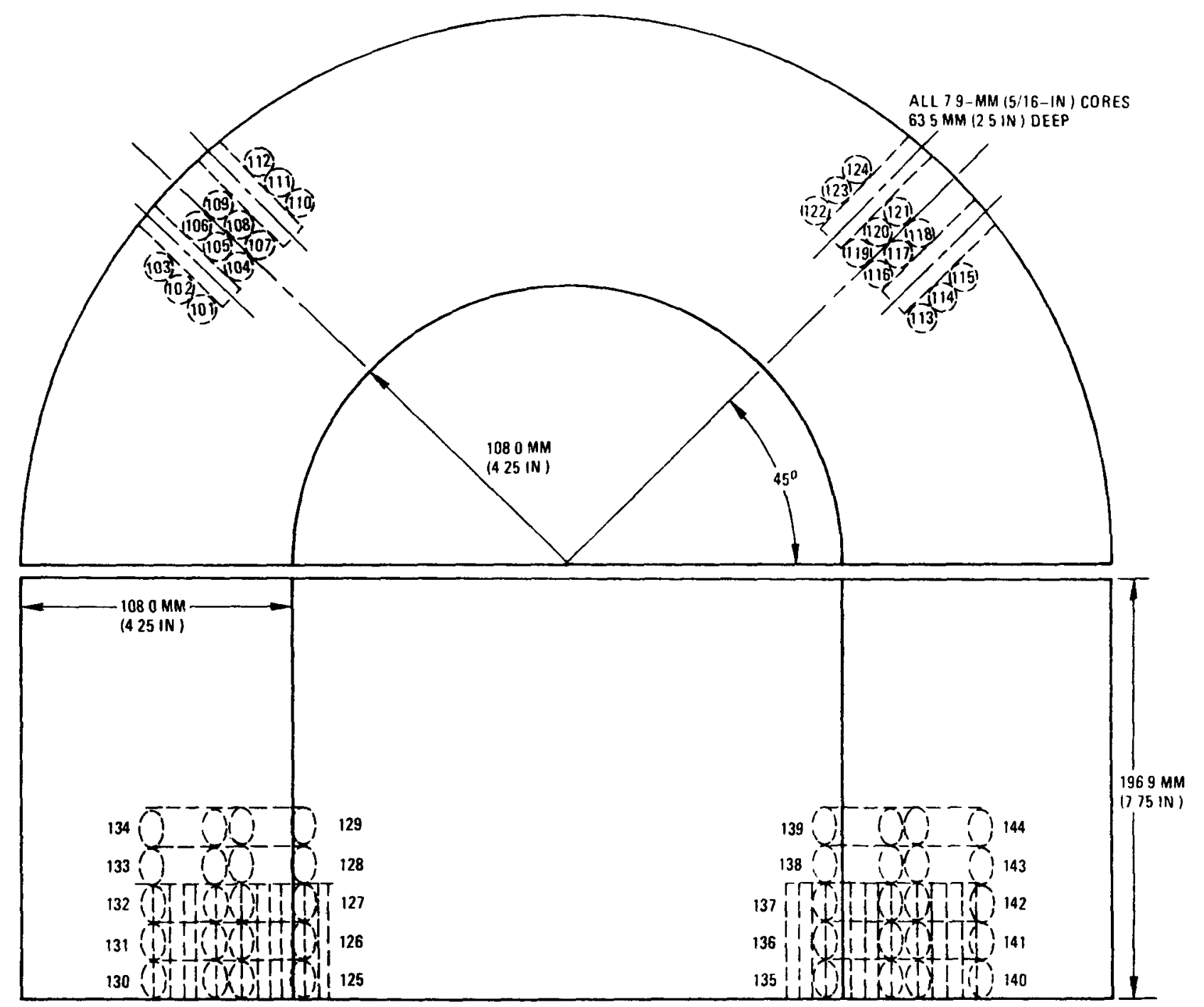

Fig. 4. Sampling diagram of slab 5A/5B: edge section 
TABLE 1

ALLOCATION OF GRAPHITE SAMPLES ${ }^{(a)}$ FOR OXIDATION STUDIES

\begin{tabular}{|c|c|c|c|c|c|c|c|c|c|c|}
\hline \multirow[b]{3}{*}{$\begin{array}{c}\text { Log-S1ab-Section } \\
\text { Number }\end{array}$} & \multicolumn{10}{|c|}{ Specimen Number } \\
\hline & \multicolumn{7}{|c|}{ Axial Direction } & \multicolumn{3}{|c|}{ Radial Direction } \\
\hline & Controls & $\begin{array}{l}1 \%(\mathrm{~b}) \\
1073 \mathrm{~K}\end{array}$ & $\begin{array}{r}2 \% \\
1073 \mathrm{~K} \\
\end{array}$ & $\begin{array}{r}4 \% \\
1073 \mathrm{~K} \\
\end{array}$ & $\begin{array}{r}1 \% \\
1273 \mathrm{~K} \\
\end{array}$ & $\begin{array}{r}2 \% \\
1273 \mathrm{~K} \\
\end{array}$ & $\begin{array}{r}4 \% \\
1273 \mathrm{~K} \\
\end{array}$ & Controls & $\begin{array}{r}4 \% \\
1073 \mathrm{~K} \\
\end{array}$ & $\begin{array}{r}4 \% \\
1273 \mathrm{~K} \\
\end{array}$ \\
\hline $6484-34-5 \mathrm{AC}$ & $\begin{array}{r}1 \\
5 \\
16 \\
20 \\
33 \\
37\end{array}$ & $\begin{array}{r}2 \\
13 \\
17 \\
26 \\
31\end{array}$ & $\begin{array}{r}3 \\
6 \\
18 \\
21 \\
23 \\
36\end{array}$ & $\begin{array}{r}4 \\
15 \\
25 \\
28 \\
34 \\
38\end{array}$ & $\begin{array}{r}8 \\
14 \\
19 \\
32 \\
35\end{array}$ & $\begin{array}{l}10 \\
12 \\
22 \\
24 \\
29\end{array}$ & $\begin{array}{r}7 \\
9 \\
11 \\
27 \\
30 \\
39\end{array}$ & $\begin{array}{l}43 \\
49 \\
54 \\
60 \\
64 \\
66\end{array}$ & $\begin{array}{l}42 \\
48 \\
52 \\
55 \\
62 \\
65\end{array}$ & $\begin{array}{l}40 \\
50 \\
56 \\
59 \\
61 \\
63\end{array}$ \\
\hline $6484-34-5 B C$ & $\begin{array}{l}11 \\
14 \\
21 \\
24 \\
26 \\
38\end{array}$ & $\begin{array}{r}1 \\
7 \\
9 \\
28 \\
33\end{array}$ & $\begin{array}{r}4 \\
15 \\
29 \\
30 \\
32 \\
34\end{array}$ & $\begin{array}{r}-3 \\
6 \\
17 \\
19 \\
23 \\
36\end{array}$ & $\begin{array}{r}2 \\
12 \\
25 \\
27 \\
31\end{array}$ & $\begin{array}{r}8 \\
13 \\
18 \\
22 \\
39\end{array}$ & $\begin{array}{r}5 \\
10 \\
16 \\
20 \\
35 \\
37\end{array}$ & $\begin{array}{l}40 \\
47 \\
52 \\
57 \\
59 \\
62\end{array}$ & $\begin{array}{l}41 \\
43 \\
44 \\
54 \\
58 \\
63\end{array}$ & $\begin{array}{l}45 \\
48 \\
51 \\
61 \\
65 \\
67\end{array}$ \\
\hline $6484-34-5 A E$ & $\begin{array}{l}101 \\
106 \\
111 \\
116 \\
121 \\
122\end{array}$ & & & $\begin{array}{l}103 \\
107 \\
112 \\
114 \\
118 \\
119\end{array}$ & & & $\begin{array}{l}102 \\
109 \\
110 \\
113 \\
117 \\
124\end{array}$ & $\begin{array}{l}128 \\
132 \\
134 \\
136 \\
138 \\
139\end{array}$ & $\begin{array}{l}126 \\
127 \\
133 \\
137 \\
141 \\
142\end{array}$ & $\begin{array}{l}129 \\
130 \\
131 \\
135 \\
143 \\
144\end{array}$ \\
\hline $6484-34-5 \mathrm{BE}$ & $\begin{array}{l}103 \\
104 \\
112 \\
115 \\
117 \\
123\end{array}$ & & & $\begin{array}{l}102 \\
106 \\
108 \\
113 \\
116 \\
122\end{array}$ & & & $\begin{array}{l}101 \\
105 \\
111 \\
114 \\
120 \\
124\end{array}$ & $\begin{array}{l}129 \\
131 \\
122 \\
136 \\
141 \\
144\end{array}$ & $\begin{array}{l}126 \\
132 \\
134 \\
137 \\
138 \\
142\end{array}$ & $\begin{array}{l}125 \\
127 \\
128 \\
135 \\
139 \\
143\end{array}$ \\
\hline
\end{tabular}

(a) Samples cored from H-451 graphite log 6484-34.

(b) Planned percent burnoff and temperature of oxidation $\left(1073 \mathrm{~K}=1472^{\circ} \mathrm{F} ; 1273 \mathrm{~K}=1832^{\circ} \mathrm{F}\right)$. 
The apparatus used for the oxidation measurements is shown in Fig. 5. Several of the cylindrical graphite specimens were simultaneously oxidized in each experiment. The specimens were supported by racks made from $\mathrm{H}-451$ graphite and contained in quartz vessels. The quartz vessels were heated to 1073 or $1273 \mathrm{~K}$ in clamshel1 resistance furnaces; temperatures were controlled to within $\pm 10 \mathrm{~K}$. During the oxidation phase, the vessels were purged with a gas mixture composed of $3 \%$ water vapor, $5 \%$ hydrogen, and $92 \%$ helium. The purge gas entered the vessels via a quartz tube which penetrated the length of the vessels along the bottom, under the graphite sample racks. Gas entered the vessels through holes drilled along the length of the entry tube. In this way, the process gas contacted all samples in a relatively uniform manner. A flow of one liter (nominal temperature and pressure) per minute of process gas was maintained throughout the tests. During periods of heat-up and cooldown, inert helium was purged through the reaction tubes. To determine the extent of oxidation, the oxidation was periodically interrupted and the samples cooled and welghed to $\pm 0.1 \mathrm{mg}$. The percent burnoff was calculated from changes in specimen weight.

It was anticipated that use of sma11-diameter samples [6.34 mm (0.25 in.)] in a hydrogen-rich gas mixture would ensure relatively uniform oxidation throughout the bulk of the samples. Uniformity of burnoff was confirmed by determining the radial density profiles for a number of nonoxidized and oxidized specimens. The specimens were weighed and dimensioned to determine their average bulk density, and the radius was reduced by predetermined increments using a precision lathe. The machined graphite residue was collected with a small vacuum filter device attached directly to the cutting tool. After each incremental cut, the sample was reweighed and dimensioned, and the density of the material removed was calculated from the weight difference of the specimen and/or the weight of the collected residue. 


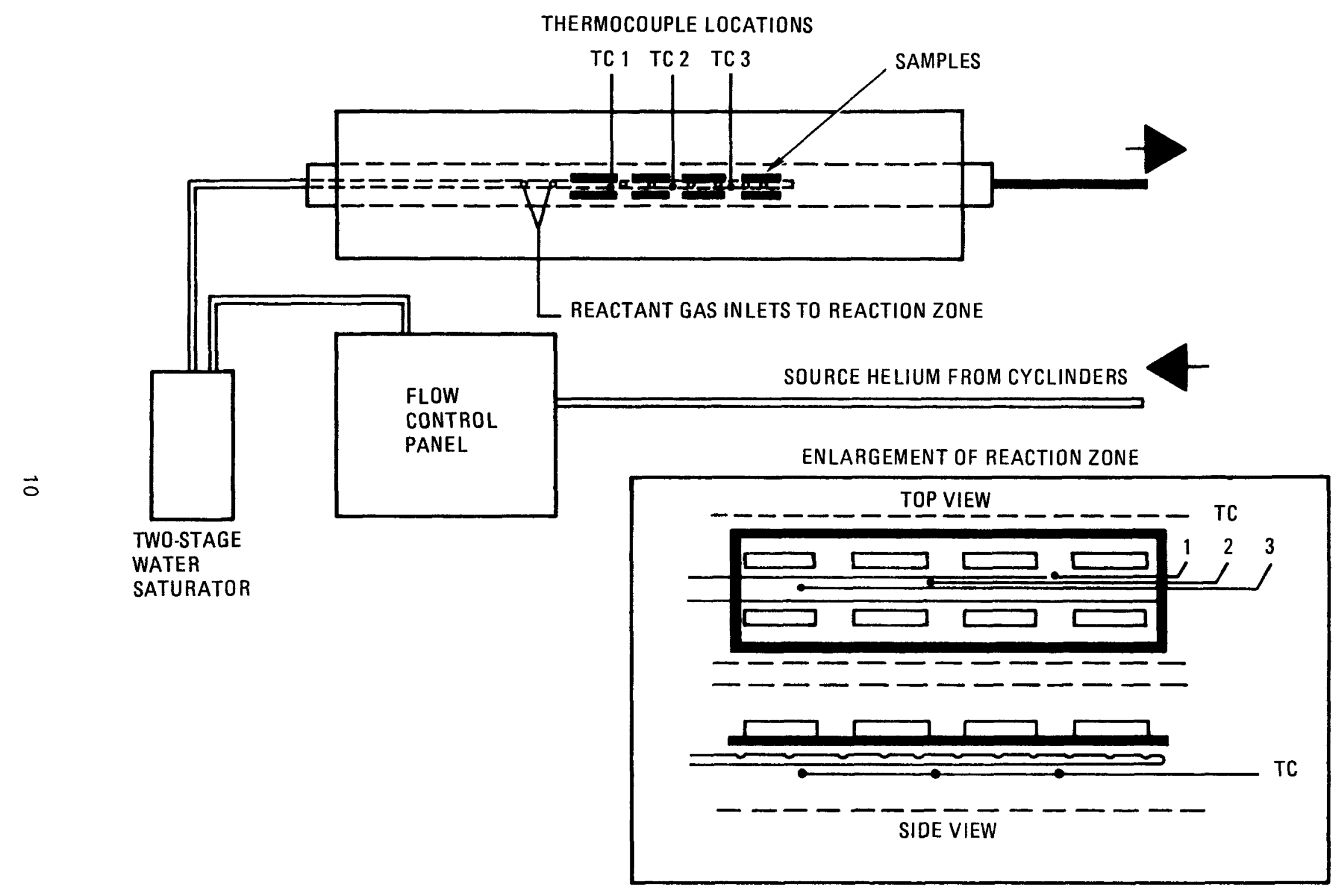

Fig. 5. Steam-graphite oxidation apparatus 


\subsection{STRENGTH, ELASTIC MODULUS, AND STRAIN AT FRACTURE MEASUREMENTS}

Tensile stress-strain curves were obtained in ambient air at room temperature using a standard method (described in Ref. 2). The UTS of each specimen was calculated by dividing the load at fracture by the original cross sectional area of the specimen. The $E$ of each specimen was calculated from its stress-strain curve as the slope of the chord drawn between points on a second loading portion of the stress-strain curve corresponding to stresses of $0.69 \mathrm{MPa}(100 \mathrm{psi})$ and $6.9 \mathrm{MPa}$ (1000 psi). This chord modulus represents the effective modulus of a graphite component after its first stress excursion (see Ref. 2 for details). Strain at fracture is $\Delta \mathrm{L} / \mathrm{L}$, where $L$ is the sample length. 


\section{EXPERIMENTAL RESULTS}

Complete data sets of UTS, E, and strain at fracture are tabulated in the Appendix.

\subsection{ULTIMATE TENSILE STRENGTH AND ELASTIC MODULUS}

The UTS data are given in Figs. 6 through 11, and the $\mathrm{E}$ data, in Figs. 12 and 13; the data are summarized in Tables 2 through 4. The UTS and E values for nonoxidized control material were highest in the axial direction, increased from center to edge (see Table 2), and are in general agreement with other data obtained for this $10 \mathrm{~g}$ and other logs of $\mathrm{H}-451$ graphite (Ref. 2).

Statistical analyses were performed on the data to (1) determine whether the distribution of UTS was Gaussian [using chi square analysis (Refs. 3,4)]; (2) compare population mean values of UTS and E for control and oxidized specimens [using the comparison of population means (CPM) test (Ref. 5)]; and (3) determine the maximum, minimum, and most probable (mean) rates of property change with burnoff at $95 \%$ confidence (using the CONFID computer code, derived from a technique given in Ref. 5).

The chi square analysis verified that the UTS data followed a Gaussian distribution. This is in agreement with the observations of Price, who found that the UTS of $H-451$ (Ref, 6) and the properties of other reactor graphites (Ref. 7) follow a Gaussian distribution. Confirmation of a Gaussian distribution is important since both the CPM test and the CONFID computer code assume Gaussian distributions. 


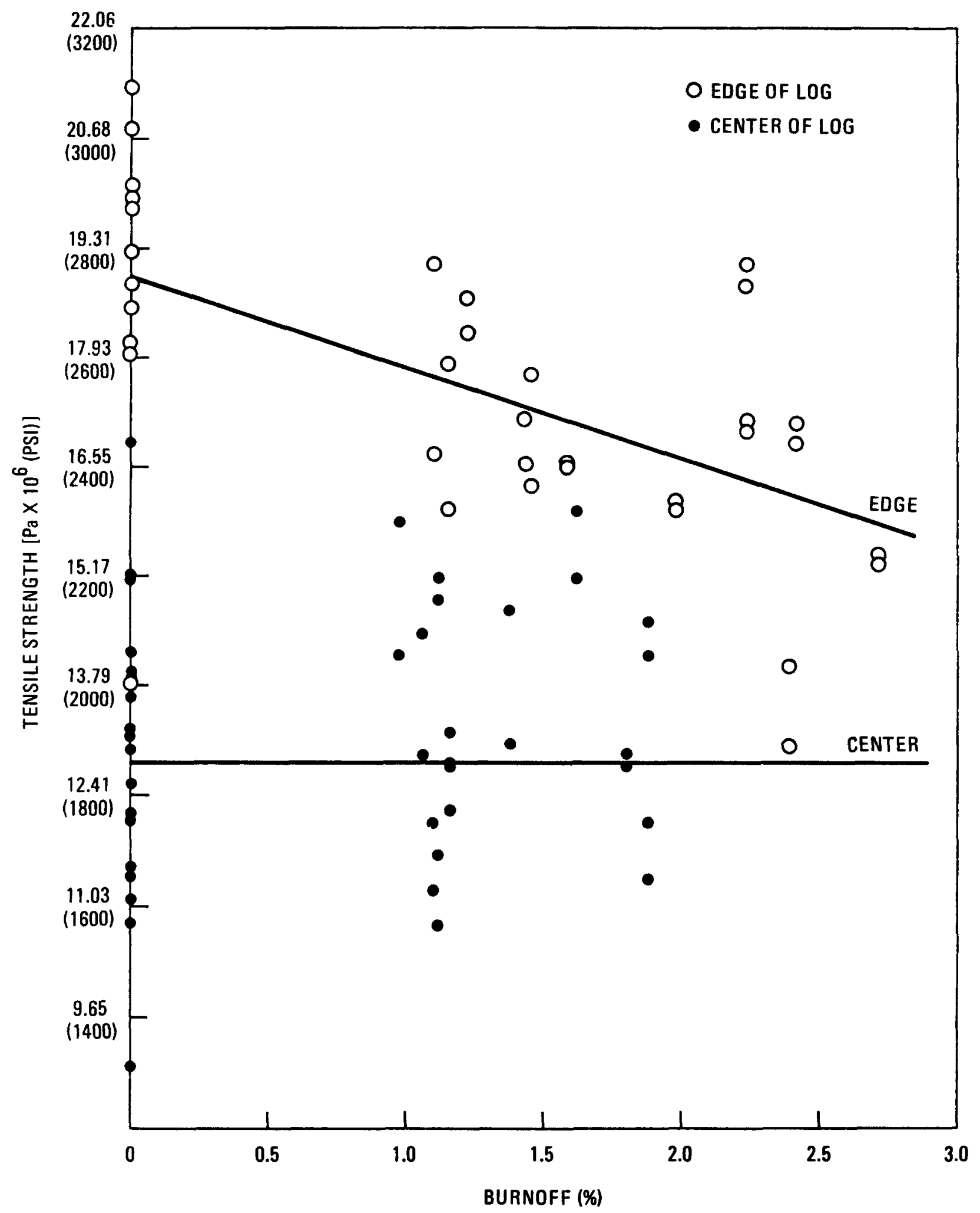

Fig. 6. Tensile strength versus burnoff for H-451 graphite (10g 6484-34) oxidized at $1073 \mathrm{~K}\left(1472^{\circ} \mathrm{F}\right)$ : quarter-length axial edge and center specimens 


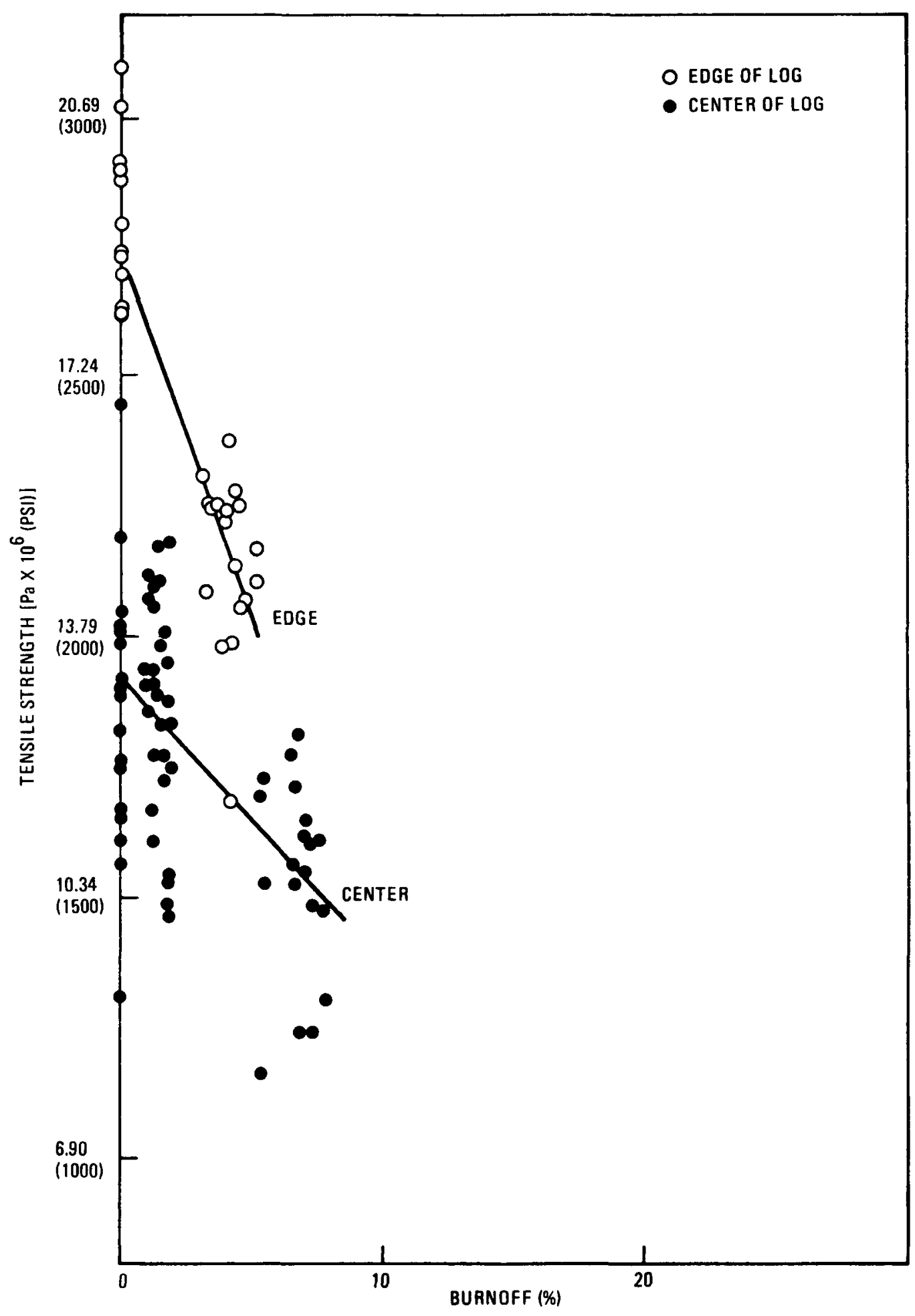

Fig. 7. Tensile strength versus burnoff for H-451 graphite ( $\log 6484-34$ ) oxidized at $1273 \mathrm{~K}\left(1832^{\circ} \mathrm{F}\right)$ : quarter-length axial edge and center specimens 


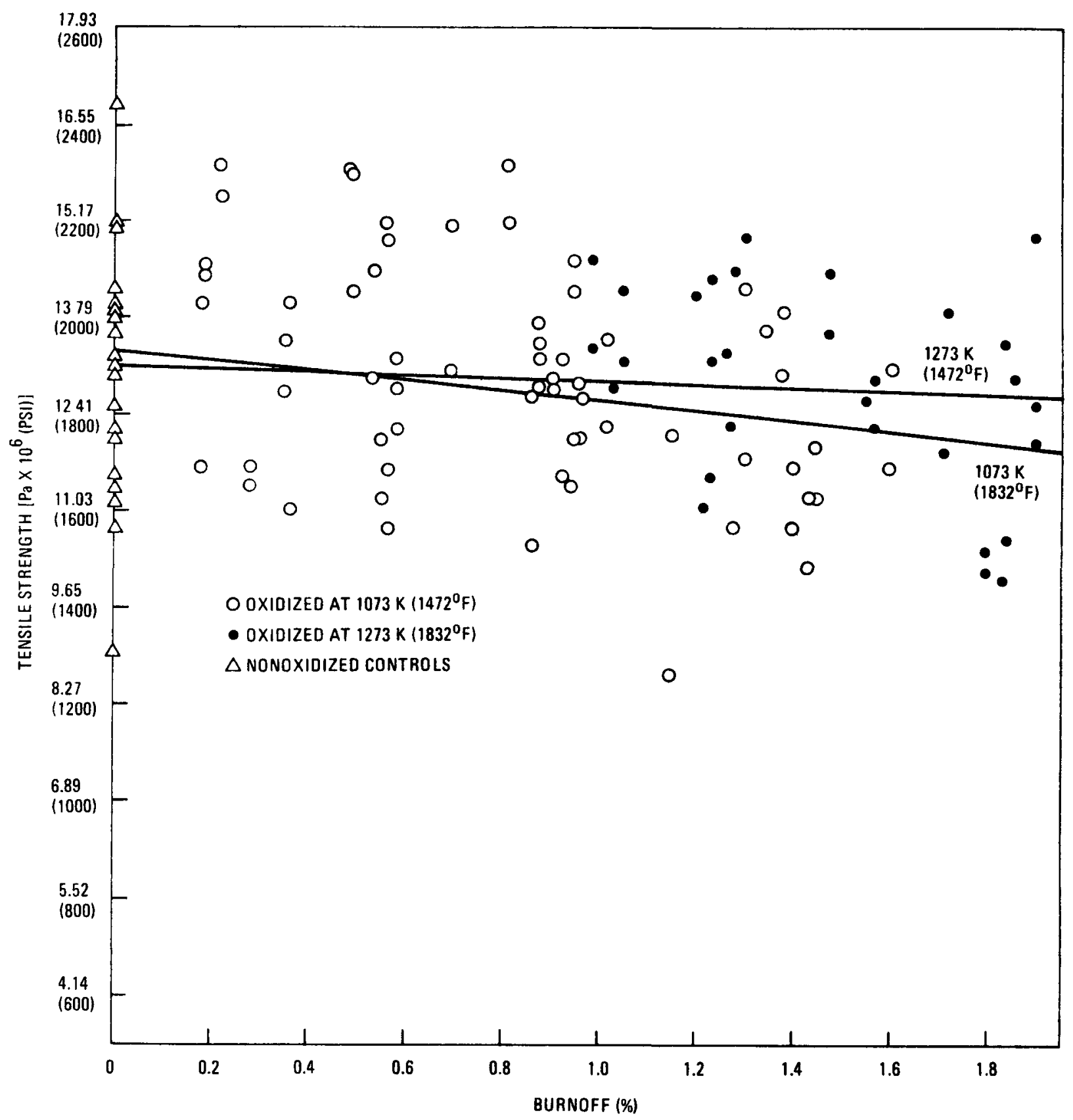

Fig. 8, Tensile strength versus burnoff for H-451 graphite ( $\log 6484-34)$ : quarter-length axial center specimens 


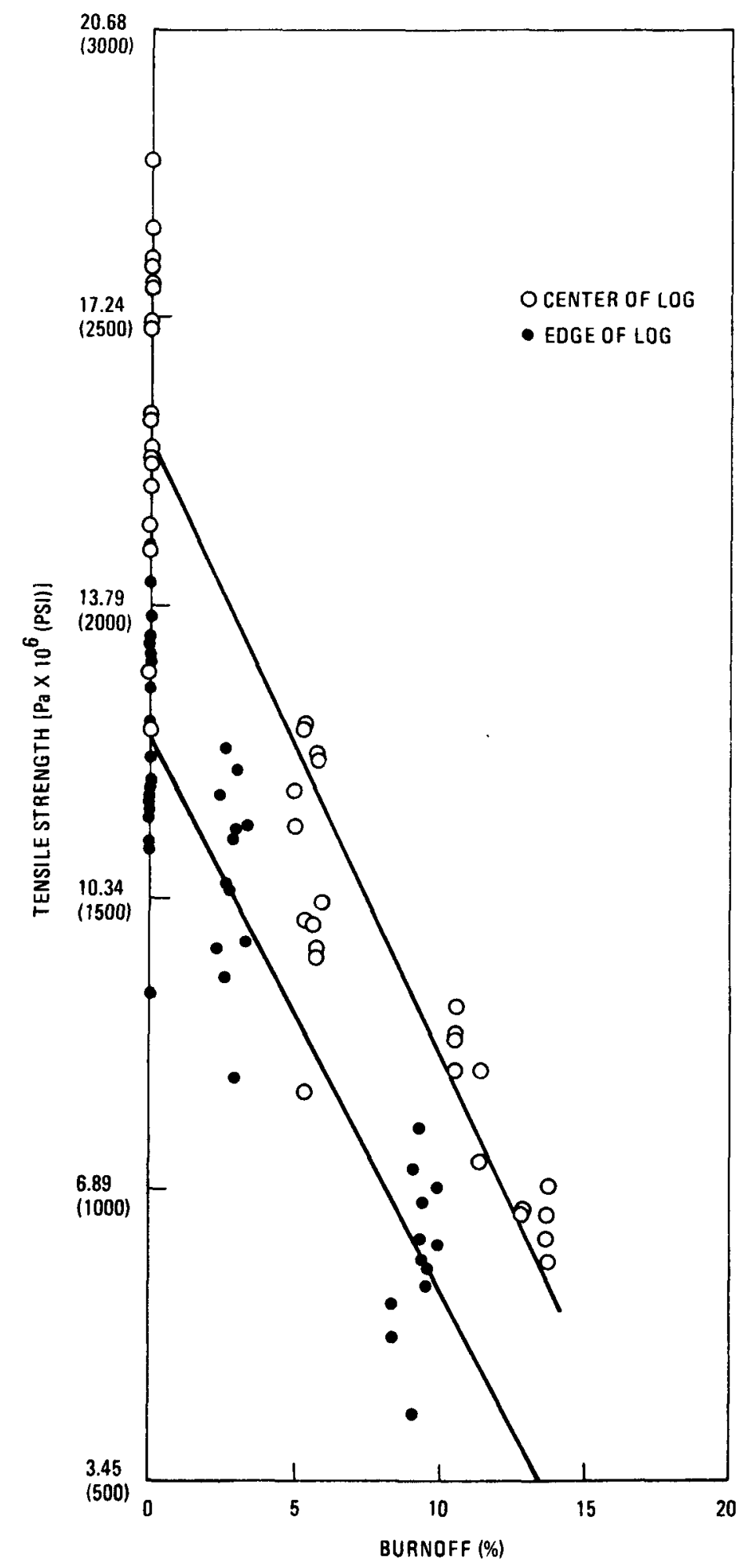

Fig. 9. Tensile strength versus burnoff for H-451 graphite (log 6484-34) oxidized at $1073 \mathrm{~K}\left(1472^{\circ} \mathrm{F}\right)$ : quarter-length radial specimens 


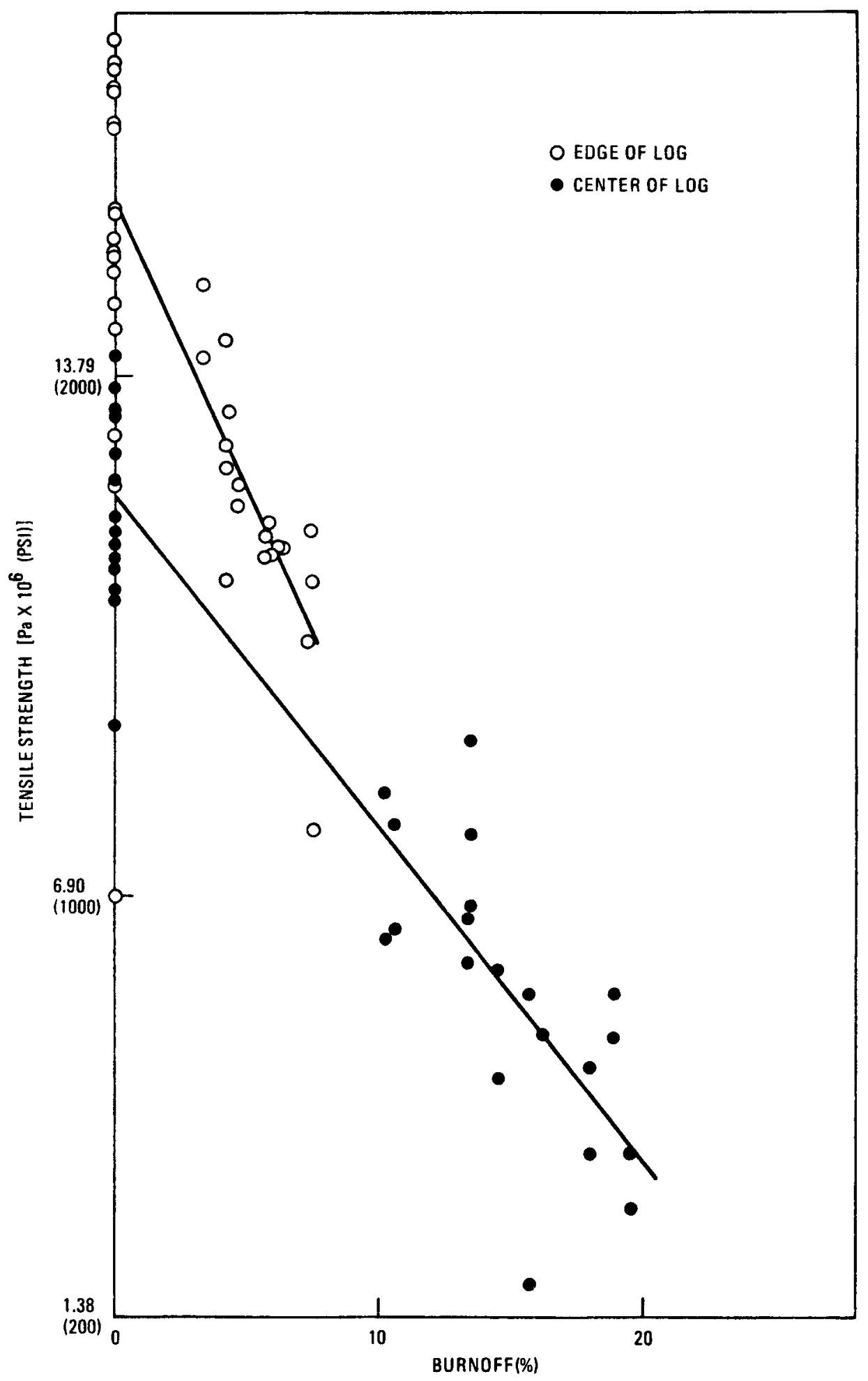

Fig. 10. Tensile strength versus burnoff for H-451 graphite ( $\log 6484-34$ ) oxidized at $1273 \mathrm{~K}\left(1832^{\circ} \mathrm{F}\right)$ : quarter-length radial specimens 


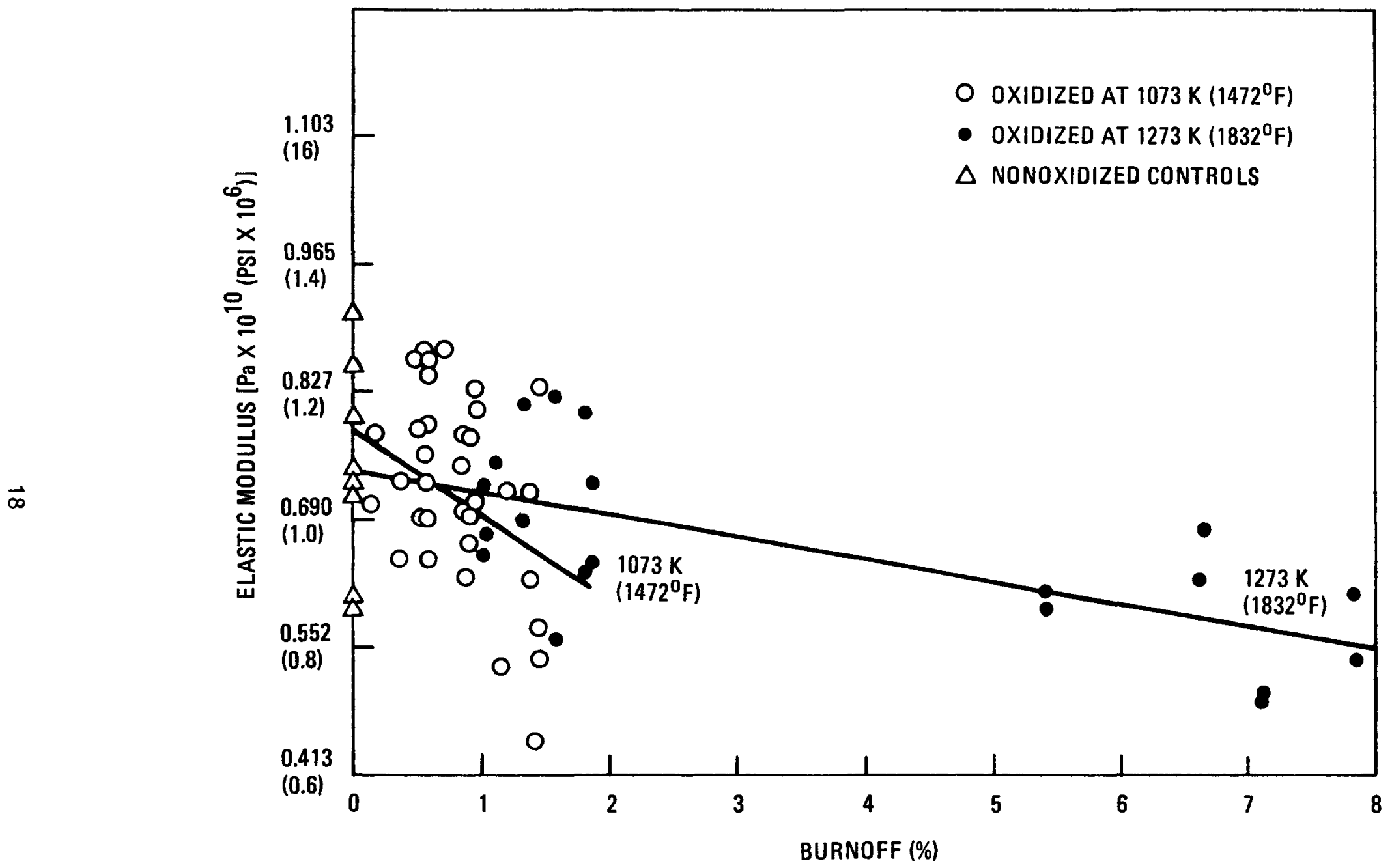

Fig. 11. Elastic modulus versus burnoff for H-451 graphite ( $\log 6484-34)$ : quarter-length axial center specimens 


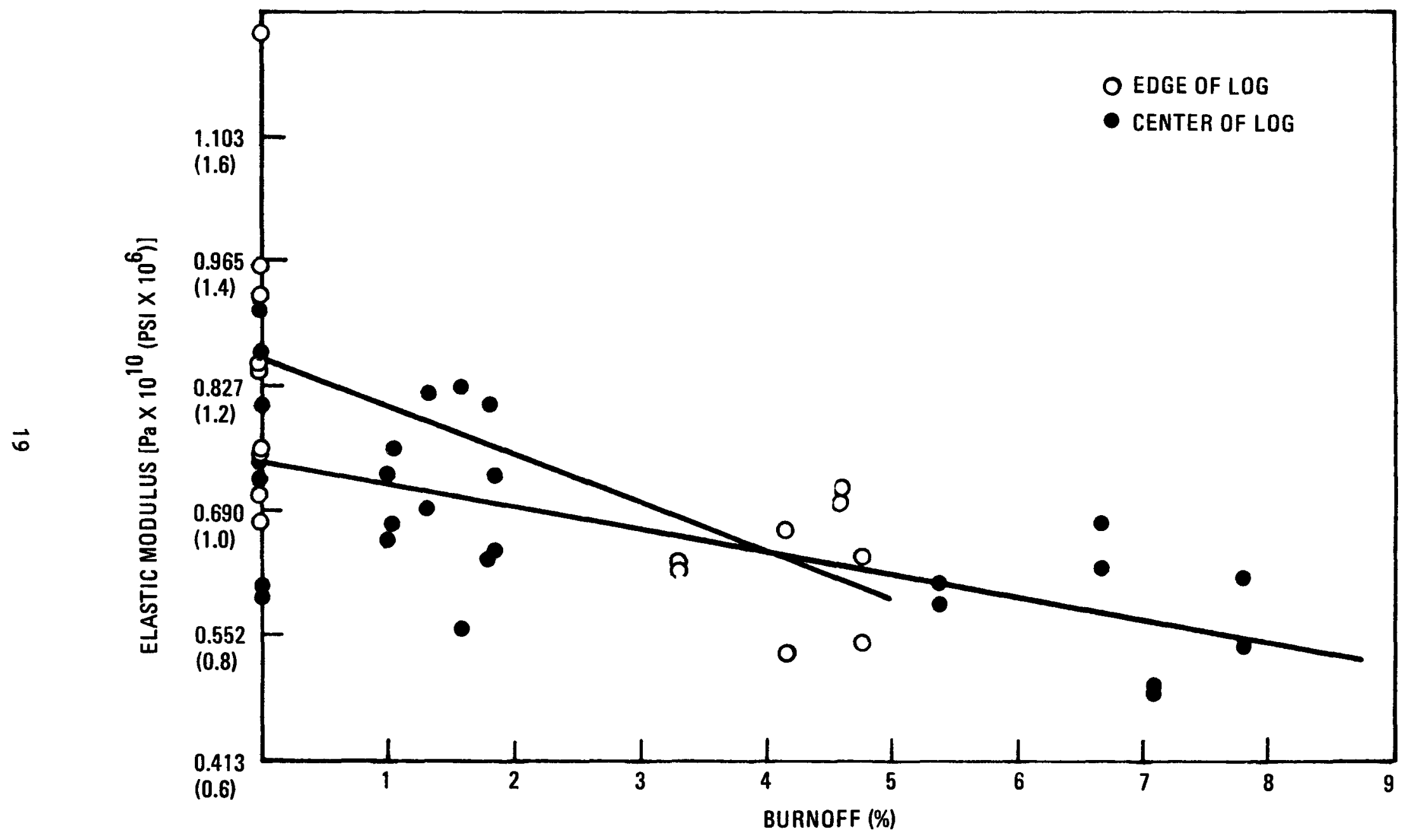

Fig. 12. Elastic modulus versus burnoff for $\mathrm{H}-451$ graphite ( $\log 6484-34)$ oxidized at $1273 \mathrm{~K}\left(1832^{\circ} \mathrm{F}\right)$ : quarter-length axial specimens 


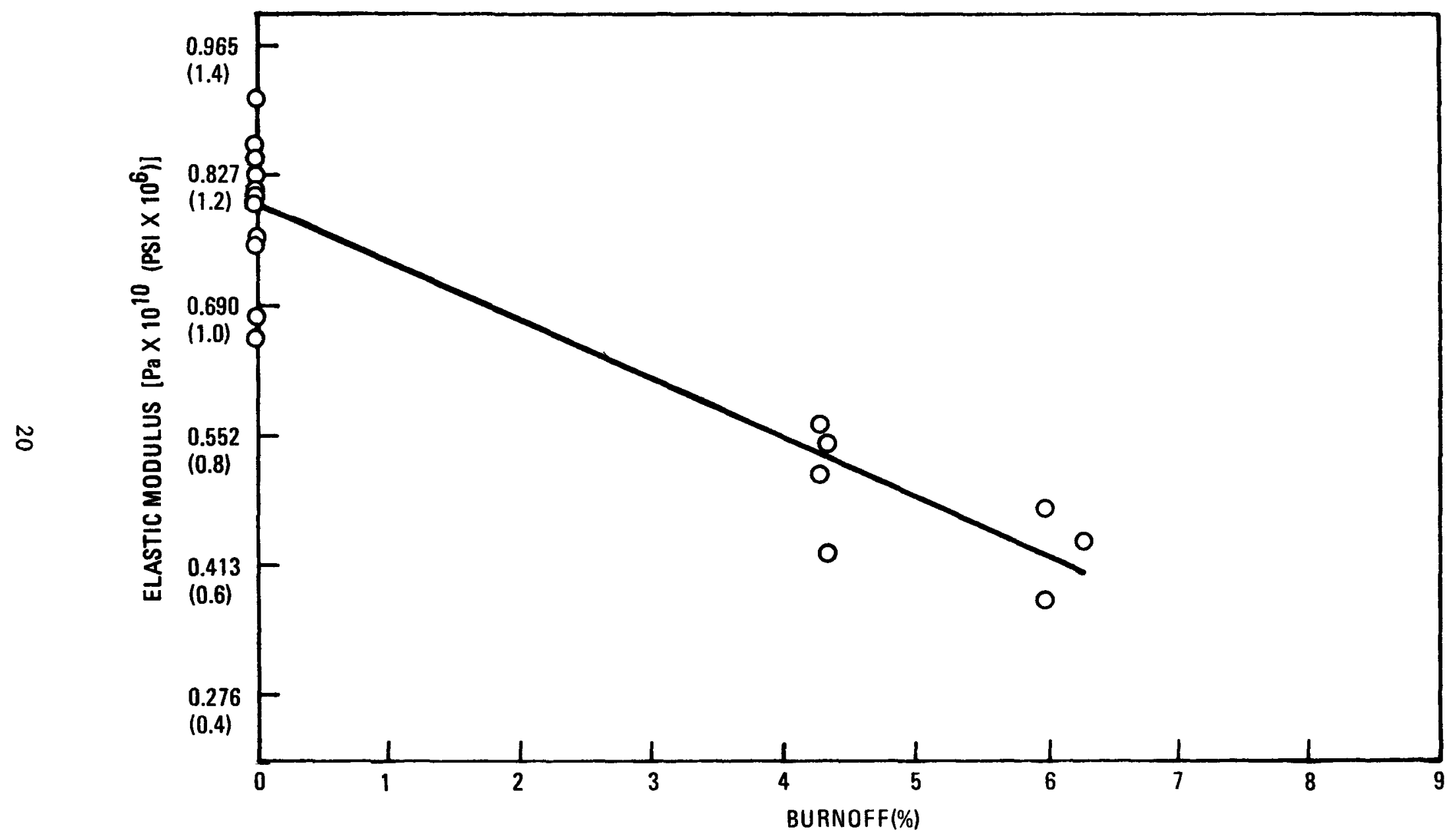

Fig. 13. Elastic modulus versus burnoff for $\mathrm{H}-451$ graphite ( $\log 6484-34)$ oxidized at $1273 \mathrm{~K}\left(1832^{\circ} \mathrm{F}\right)$ : quarter-length radial edge specimens 
TABLE 2

MEAN ULTIMATE TENSILE STRENGTH AND MEAN ELASTIC MODULUS FOR NONOXIDIZED CONTROL SPECIMENS (a)

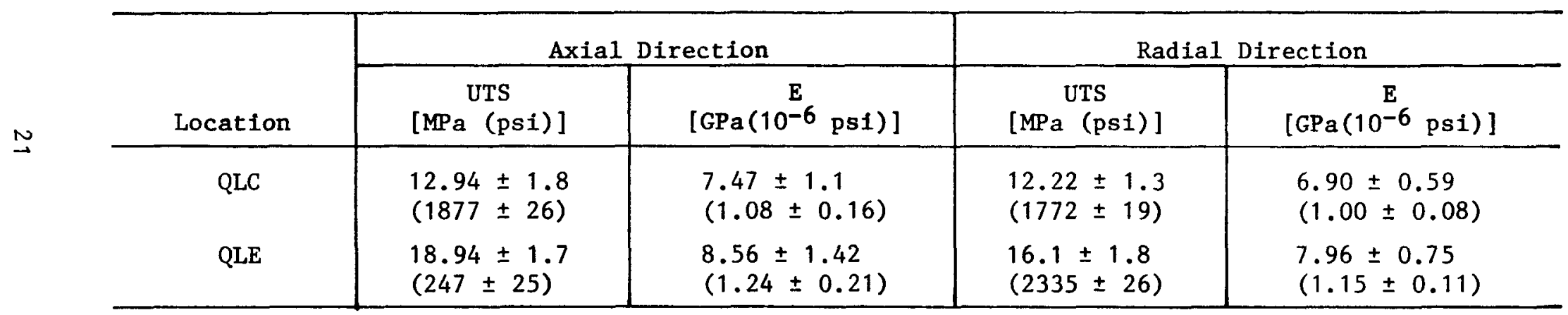

(a) $\log 6384-34$. 
TABLE 3

SUMMARY OF MECHANICAL PROPERTIES AND COMPARISON OF POPULATION MEANS FOR QUARTER-LENGTH SAMPLES FROM H-45i(a)

\begin{tabular}{|c|c|c|c|c|c|c|c|c|c|c|}
\hline \multirow{2}{*}{$\begin{array}{c}\text { Location } \\
\text { and } \\
\text { Orientation (b) } \\
\end{array}$} & \multicolumn{2}{|c|}{ Oxidation } & \multicolumn{4}{|c|}{ Ultimate Tensile Strength } & \multicolumn{4}{|c|}{ Elastic Modulus } \\
\hline & $\begin{array}{c}\text { Temperature } \\
{\left[\mathrm{K}\left({ }^{\circ} \mathrm{F}\right)\right]}\end{array}$ & $\begin{array}{c}\text { Burnoff } \\
(\%)\end{array}$ & $\begin{array}{c}\text { Mean } \\
{[\mathrm{MPA}(\mathrm{psi})]}\end{array}$ & $\begin{array}{c}\text { Standard Deviation } \\
{[\mathrm{MPa}(\mathrm{ps} i)]}\end{array}$ & \begin{tabular}{|c|} 
Number of \\
Data Points \\
\end{tabular} & $\begin{array}{r}\text { CPM Teqt } \\
\text { Results }\end{array}$ & {$\left[\begin{array}{c}\text { Mean } \\
{\left[\mathrm{GPa}\left(10^{-6} \mathrm{ps} 1\right)\right]}\end{array}\right.$} & $\begin{array}{l}\text { Standard Deviation } \\
{\left[\mathrm{CPa}\left(10^{-6} \mathrm{ps} 1\right)\right]}\end{array}$ & $\begin{array}{c}\text { Number of } \\
\text { Data Points }\end{array}$ & \begin{tabular}{|l|} 
CPM Test \\
Results (c)
\end{tabular} \\
\hline $\mathrm{CA}$ & -- & 0 & $\begin{array}{l}12.9 \\
(1870)\end{array}$ & $1.8(261)$ & 19 & - & 7.5 & $1.1(0.16)$ & 8 & -- \\
\hline $\mathrm{CA}$ & $1073(1472)$ & 0.7 to 0.36 & $\begin{array}{l}13.4 \\
(1944)\end{array}$ & $1.7(247)$ & 12 & NSD & $\begin{array}{l}7.2 \\
(1.04)\end{array}$ & $0.6(0.09)$ & 4 & NSD \\
\hline $\mathrm{CA}$ & $1073(1472$ & 0.49 to 0.69 & $\begin{array}{l}13.2 \\
(1915)\end{array}$ & $1.5(217)$ & 16 & NSD & $\begin{array}{l}7.9 \\
(1.15)\end{array}$ & $0.77(0.11)$ & 13 & NSD \\
\hline $\mathrm{CA}$ & $1073(1472)$ & 0.86 to 1.60 & $\begin{array}{l}12.5 \\
(1813)\end{array}$ & $1.4(203)$ & 37 & NSD & $\begin{array}{l}6.9 \\
(1.00)\end{array}$ & $1.1(0.16)$ & 19 & SD \\
\hline $\mathrm{CA}$ & $1273(1832)$ & 0.99 to 1.30 & $\begin{array}{l}13.4 \\
(1944)\end{array}$ & $1.2(174)$ & 14 & NSD & $\begin{array}{l}7.1 \\
(1.03)\end{array}$ & $0.6(0.09)$ & 8 & NSD \\
\hline $\mathrm{CA}$ & $1273(1832)$ & 1.47 to 1.90 & $\begin{array}{l}12.5 \\
(1813)\end{array}$ & $1.5(217)$ & 16 & NSD & $\begin{array}{l}7.0 \\
(1.02)\end{array}$ & $1.0(0.15)$ & 8 & NSD \\
\hline $\mathrm{CA}$ & $1273(1832)$ & 5.38 to 7.83 & $\begin{array}{l}10.7 \\
(1552)\end{array}$ & $1.3(189)$ & 20 & SD & $\begin{array}{l}5.8 \\
(0.84)\end{array}$ & $0.7(0.10)$ & 8 & SD \\
\hline CR & - & 0 & $\begin{array}{l}12.2 \\
(1769)\end{array}$ & $1.3(189)$ & 20 & -- & $\begin{array}{l}6.9 \\
(1.00)\end{array}$ & $0.6(0.09)$ & 9 & -- \\
\hline CR & $1073(1472)$ & 0.25 to 0.33 & $\begin{array}{l}10.6 \\
(1537)\end{array}$ & $1.1(160)$ & 12 & SD & -- & -- & -- & -- \\
\hline$C R$ & $1073(1472)$ & 8.4 to 10.0 & $\begin{array}{l}6.1 \\
(885)\end{array}$ & $0.9(131)$ & 12 & SD & -- & -- & -- & -- \\
\hline CR & $1273(1832)$ & 10.2 to 14.5 & $\begin{array}{l}6.9 \\
\text { (1000 }\end{array}$ & $1.2(174)$ & 12 & SD & - & -- & -- & - \\
\hline CR & $1273(1832)$ & 15.7 to 19.6 & $\begin{array}{l}4.2 \\
(609)\end{array}$ & $1.3(189)$ & 9 & SD & - & -- & -- & -- \\
\hline E.A & -- & 0 & $\begin{array}{l}18.9 \\
(2741)\end{array}$ & $1.7(247)$ & 15 & -- & $\begin{array}{l}8.6 \\
(1.25)\end{array}$ & $1.4(0.20)$ & 12 & -- \\
\hline EA & $1073(1472)$ & 1.0 to 2.5 & $\begin{array}{l}16.8 \\
(2437)\end{array}$ & $1.4(203)$ & 24 & SD & - & -- & -- & -- \\
\hline EA & $1273(1832)$ & 3.3 to 5.2 & $\begin{array}{l}14.8 \\
(2147)\end{array}$ & $1.1(160)$ & 20 & SD & $\begin{array}{l}6.3 \\
(0.91)\end{array}$ & $0.7(0.10)$ & 8 & SD \\
\hline ER & - & 0 & $\begin{array}{l}16.1 \\
(2335)\end{array}$ & $1.8(261)$ & 18 & -- & $\begin{array}{l}8.0 \\
(1.16)\end{array}$ & $0.8(0.12)$ & 11 & -- \\
\hline ER & $1073(1472)$ & 0.49 to 0.59 & $\begin{array}{l}10.7 \\
(1552)\end{array}$ & $1.3(189)$ & 12 & SD & -- & -- & - & -- \\
\hline ER & $1073(1472)$ & 10.5 to 13.8 & $\begin{array}{l}7.4 \\
(1073)\end{array}$ & $1.1(160)$ & 12 & SD & -- & -- & -- & -- \\
\hline ER & $1273(1832)$ & 3.4 to 4.8 & $\begin{array}{l}13.0 \\
(1885)\end{array}$ & $1.2(174)$ & 9 & SD & $\begin{array}{l}5.1 \\
(0.74)\end{array}$ & $0.6(0.09)$ & 4 & SD \\
\hline ER & $1273(1832)$ & 5.8 to 7.6 & $\begin{array}{l}10.9 \\
(1581)\end{array}$ & $1.3(189)$ & 10 & SD & $\begin{array}{l}4.3 \\
(0.62)\end{array}$ & $0.4(0.06)$ & 4 & SD \\
\hline ER & $1273(1832)$ & 3.4 to 7.6 & $\begin{array}{l}11.9 \\
(1726)\end{array}$ & $1.6(232)$ & 19 & SD & $\begin{array}{l}4.7 \\
(0.68)\end{array}$ & $0.7(0.10)$ & 8 & SD \\
\hline
\end{tabular}

(a) $\log 6484-34$.

(b) $\mathrm{CA}$ = center axial specimens; $\mathrm{CR}$ = center radial specimens; $\mathrm{EA}=$ edge axial specimens; $\mathrm{ER}$ = edge radial specimens.

(c) ${ }_{\text {NSD }}=$ no significant difference $(95 \%$ confidence) between property averages of controls and oxidized samples; SD = significant difference ( $95 \%$ confidence) between property averages of controls and oxidized samples. 
TABLE 4

REDUCTION IN ULTIMATE TENSILE STRENGTH AND ELASTIC MODULUS WITH OXIDATION

\begin{tabular}{|c|c|c|c|c|c|}
\hline \multirow[b]{2}{*}{ Location (a) } & \multirow[b]{2}{*}{$\begin{array}{c}\text { Burnoff } \\
\text { Temperature } \\
{\left[\mathrm{K}\left({ }^{\circ} \mathrm{F}\right)\right]}\end{array}$} & \multirow[b]{2}{*}{$\begin{array}{c}\text { Burnoff } \\
\text { Range } \\
(\%)\end{array}$} & \multicolumn{3}{|c|}{$\%$ Reduction/1\% Burnoff } \\
\hline & & & $\begin{array}{c}\text { Maximum } \\
2.3 \% \\
\text { Probability }\end{array}$ & $\begin{array}{c}\text { Mean } \\
\text { (Most Probable) }\end{array}$ & $\begin{array}{c}\text { Minimum } \\
2.3 \% \\
\text { Probability }\end{array}$ \\
\hline $\mathrm{CA}$ & $1073(1472)$ & 0 to 2 & 11.17 & 5.60 & 0.0 \\
\hline $\mathrm{CA}$ & $1273(1832)$ & 0 to 2 & 7.32 & 1.73 & 0.0 \\
\hline $\mathrm{CA}$ & $1273(1832)$ & 0 to 8 & 3.85 & 2.82 & 1.70 \\
\hline EA & $1273(1832)$ & 0 to 6 & 6.48 & 5.14 & 3.74 \\
\hline $\mathrm{CR}$ & $1073(1472)$ & 0 to 10 & 6.06 & 5.32 & 4.32 \\
\hline ER & $1073(1472)$ & 0 to 14 & 5.14 & 4.60 & 3.23 \\
\hline CR & $1273(1832)$ & 0 to 20 & 3.92 & 3.59 & 3.18 \\
\hline ER & $1273(1832)$ & 0 to 8 & 5.93 & 4.79 & 3.72 \\
\hline & & & $\mathrm{E}$ & & \\
\hline $\mathrm{CA}$ & $1073(1472)$ & 0 to 2 & 19.04 & 10.46 & 0.01 \\
\hline $\mathrm{CA}$ & $1273(1832)$ & 0 to 2 & 11.56 & 3.71 & 0.0 \\
\hline $\mathrm{CA}$ & $1273(1832)$ & 0 to 8 & 4.88 & 3.26 & 1.45 \\
\hline EA & $1273(1832)$ & 0 to 5 & 9.53 & 6.10 & 1.96 \\
\hline ER & $1273(1832)$ & 0 to 6 & 9.31 & 7.83 & 6.11 \\
\hline
\end{tabular}

${ }^{(a)} \mathrm{CA}=$ center axial specimens; $\mathrm{EA}=$ edge axial specimens; $\mathrm{CR}=$ center radial specimens; $E R=$ edge radial specimens. 
The results of the CPM and CONFID analyses are given in Tables 3 and 4 , respectively. The rates of changes in UTS and E from the CONFID calculations are illustrated in Figs. 6 through 13, where the most probable rate changes are shown as linear regression lines. A comparison of nonoxidized and oxidized UTS values showed strength to decrease with oxidation. The population means of the control and oxidized specimens were also compared (Table 3), and no significant reduction in UTS or $\mathrm{E}$ was observed at $95 \%$ confidence in axial specimens oxidized up to $2 \%$ and $1 \%$ burnoff, respectively.

The effect of oxidation on UTS for axial edge and center specimens oxidized at $1073 \mathrm{~K}\left(1472^{\circ} \mathrm{F}\right)$ is shown in Fig. 6. There was no decrease in strength in the center specimens up to $2 \%$ burnoff, whereas a slight decrease was observed in the edge specimens. The UTS reduction rates for $1273 \mathrm{~K}$ $\left(1832^{\circ} \mathrm{F}\right)$ oxidation are shown in Fig. 7. Again, the edge specimens lost strength at a higher rate than the center specimens. The combined data for axial center samples at low burnoffs are shown in Fig. 8. No strength reduction was observed for burnoffs of up to $2 \%$ at either 1073 or $1273 \mathrm{~K}$ $\left(1472^{\circ}\right.$ or $\left.1832^{\circ} \mathrm{F}\right)$. The UTS data for radial edge and center specimens are presented in Figs. 9 and 10 for oxidation at 1073 and $1273 \mathrm{~K}\left(1472^{\circ}\right.$ and $1832^{\circ} \mathrm{F}$ ), respectively. The radial specimens lost strength at a faster rate than the axial specimens, and in both cases the edge specimens lost strength at a faster rate than the center specimens.

The effect of oxidation on the $E$ of axial center specimens at 1073 and $1273 \mathrm{~K}\left(1472^{\circ}\right.$ and $\left.1832^{\circ} \mathrm{F}\right)$ is given in Fig. 11. There was no effect of burnoffs of up to $1 \%$, but above $1 \%$ the reduction of $\mathrm{E}$ was significant. Changes in the $\mathrm{E}$ of axial center and edge specimens are compared in Fig. 12. The $\mathrm{E}$ of the edge specimens was reduced at a higher rate than that of the center specimens. A plot of elastic modulus versus burnoff for radial specimens oxidized at $1273 \mathrm{~K}\left(1832^{\circ} \mathrm{F}\right)$ is shown in Fig. 13. 
All trends for UTS and E are summarized in Table 4 by comparing the relative reduction of each property at $1 \%$ burnoff. The results in Table 4 were obtained from CONFID, which can be used to calculate at $95 \%$ confidence the most probable (50\% probability) or "mean" decrease in property and the maximum and minimum (2.3\% probability) decrease in property. The reductions in UTS and $E$ were greater when the specimens were oxidized at $1073 \mathrm{~K}\left(1472^{\circ} \mathrm{F}\right)$ compared with $1273 \mathrm{~K}\left(1832^{\circ} \mathrm{F}\right)$. Also, as noted previously, changes in UTS and $E$ were greater for edge specimens than for center specimens. This phenomenon was particularly significant for the modulus data, where the average decrease in edge specimens at $1273 \mathrm{~K}\left(1832^{\circ} \mathrm{F}\right)$ was twice that of the center specimens.

\subsection{STRAIN AT FRACTURE}

Changes in strain at fracture were measured for controls and specimens oxidized to burnoffs of up to $12 \%$; these data are presented in Table 5 . The data were anomalous, showing no changes in axial center specimens at $4.3 \%$ burnoff, about $50 \%$ reduction in radial center specimens at $2.8 \%$ to 9.3\% burnoff, and about $40 \%$ in radial edge specimens at $5.5 \%$ to $12 \%$ burnoff. No firm conclusions can be drawn from these data.

\subsection{OXIDATION-INDUCED BULK DENSITY PROFILES}

Bulk density profiles for a nonoxidized control specimen of $\mathrm{H}-451$ and for three oxidized specimens are given in Figs. 14 through 17. The large scatter in the data is due to (1) experimental difficulties in measuring sma11 changes in weight and dimensions, (2) the heterogeneous nature of the graphite, and (3) the relatively large H-451 particle sizes, which lead to some tearing out of graphite particles during machining. When a large number of increments were taken across the radius of a specimen [about $1.5 \mathrm{~mm}$ (0.06 in.) for an initial diameter of $6.3 \mathrm{~mm}$ (0.25 in.)], the scatter in the data tends to be average. The final central core of the machined specimens [diameter $\sim 3 \mathrm{~mm}(0.12 \mathrm{in.})$ ], which can be accurately determined, was used as the final data point on the curves in Figs. 14 through 
TABLE 5

EFFECT OF OXIDATION ON STRAIN AT FRACTURE

\begin{tabular}{|c|c|c|c|c|c|c|}
\hline \multirow{2}{*}{$\begin{array}{l}\text { Location } \\
\text { In Slab } \\
\end{array}$} & \multirow{2}{*}{$\begin{array}{c}\text { Specimen } \\
\text { Orientation } \\
\end{array}$} & \multirow{2}{*}{$\begin{array}{c}\text { Mean Value } \\
(\%) \\
\end{array}$} & \multirow{2}{*}{$\begin{array}{c}\text { Standard } \\
\text { Deviation } \\
(\%)\end{array}$} & \multirow{2}{*}{$\begin{array}{l}\text { Number of } \\
\text { Specimens } \\
\text { Tested }\end{array}$} & \multicolumn{2}{|c|}{ Burnoff (\%) } \\
\hline & & & & & Range & Average \\
\hline Edge & Axial & $0.36(a)$ & 0.04 & 7 & Contro1 & \\
\hline Edge & Axial & $0.33^{(a)}$ & 0.03 & 8 & 3.3 to 5.2 & 4.3 \\
\hline Center & Radial & 0.28 & 0.04 & 9 & Control & \\
\hline Center & Radial & $\begin{array}{l}0.13 \\
0.13\end{array}$ & $\begin{array}{l}0.02 \\
0.02\end{array}$ & $\begin{array}{l}10 \\
11\end{array}$ & $\begin{array}{l}2.6 \text { to } 3.3 \\
8.4 \text { to } 10.0\end{array}$ & $\begin{array}{l}2.80 \\
9.31\end{array}$ \\
\hline Edge & Radial & 0.32 & 0.04 & 10 & Control & \\
\hline Edge & Radial & $\begin{array}{l}0.17 \\
0.19\end{array}$ & $\begin{array}{l}0.02 \\
0.02\end{array}$ & $\begin{array}{l}11 \\
12\end{array}$ & $\begin{array}{l}5.0 \text { to } 5.9 \\
10.5 \text { to } 12.8\end{array}$ & $\begin{array}{r}5.5 \\
12.1\end{array}$ \\
\hline
\end{tabular}

(a) Judged not significantly different at $95 \%$ confidence level using student's t-test. 


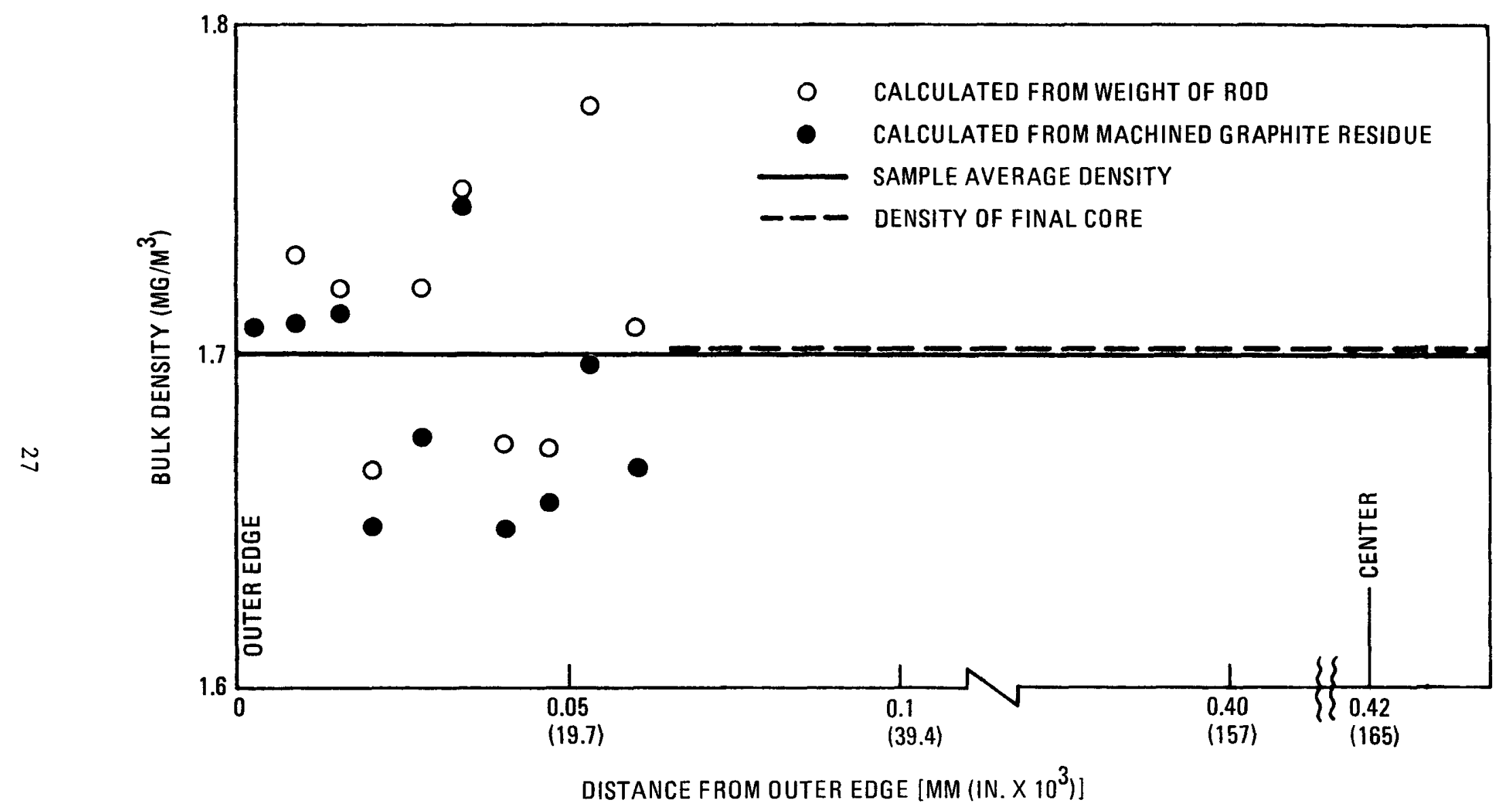

Fig. 14. Bulk density profile of H-451 graphite: $0 \%$ burnoff 


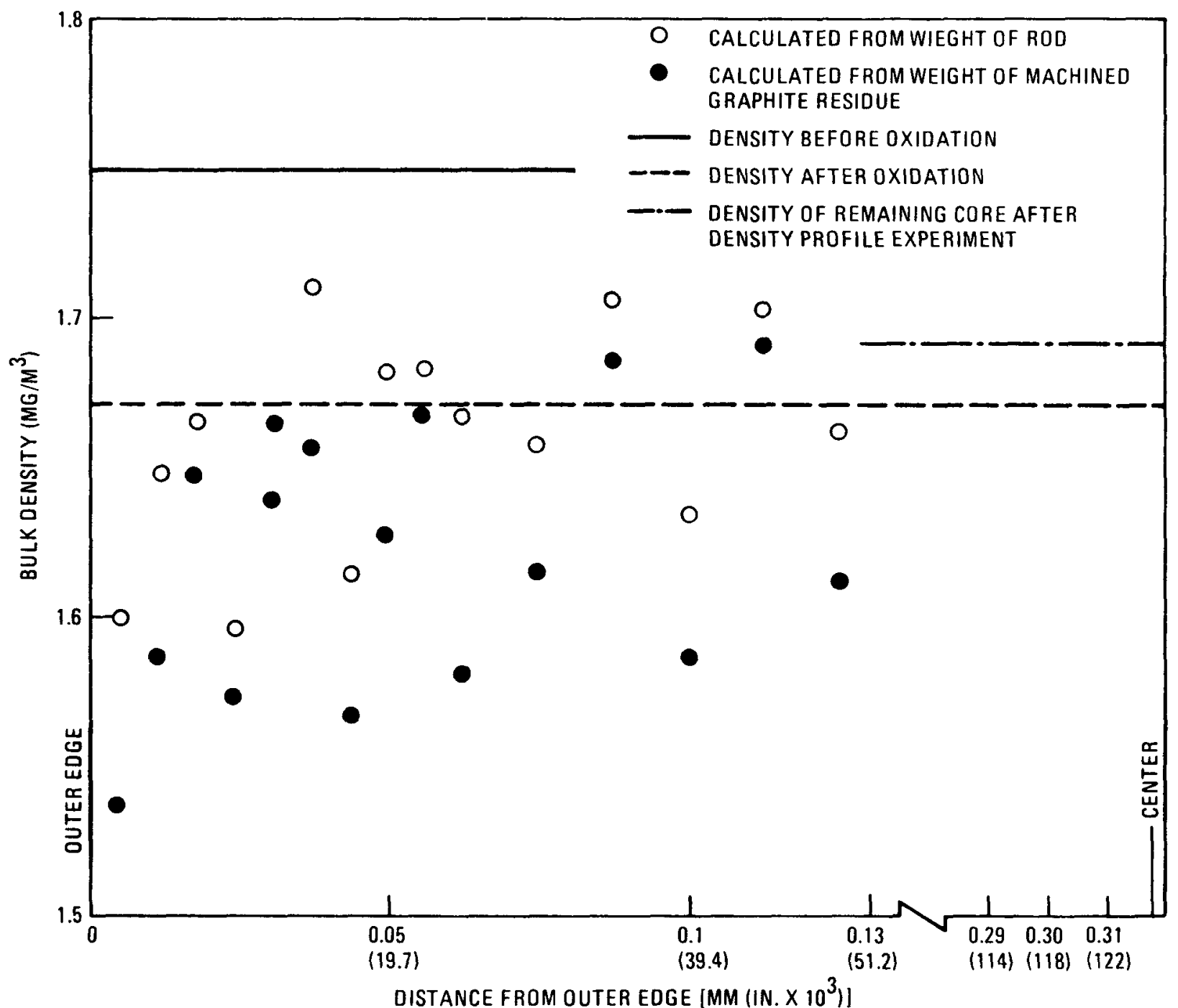

Fig. 15. Bulk density profile of H-451 graphite (sample 6484-34-5B): quarter-length axial center specimen oxidized at $1073 \mathrm{~K}\left(1472^{\circ} \mathrm{F}\right)$ to $0.96 \%$ burnoff 


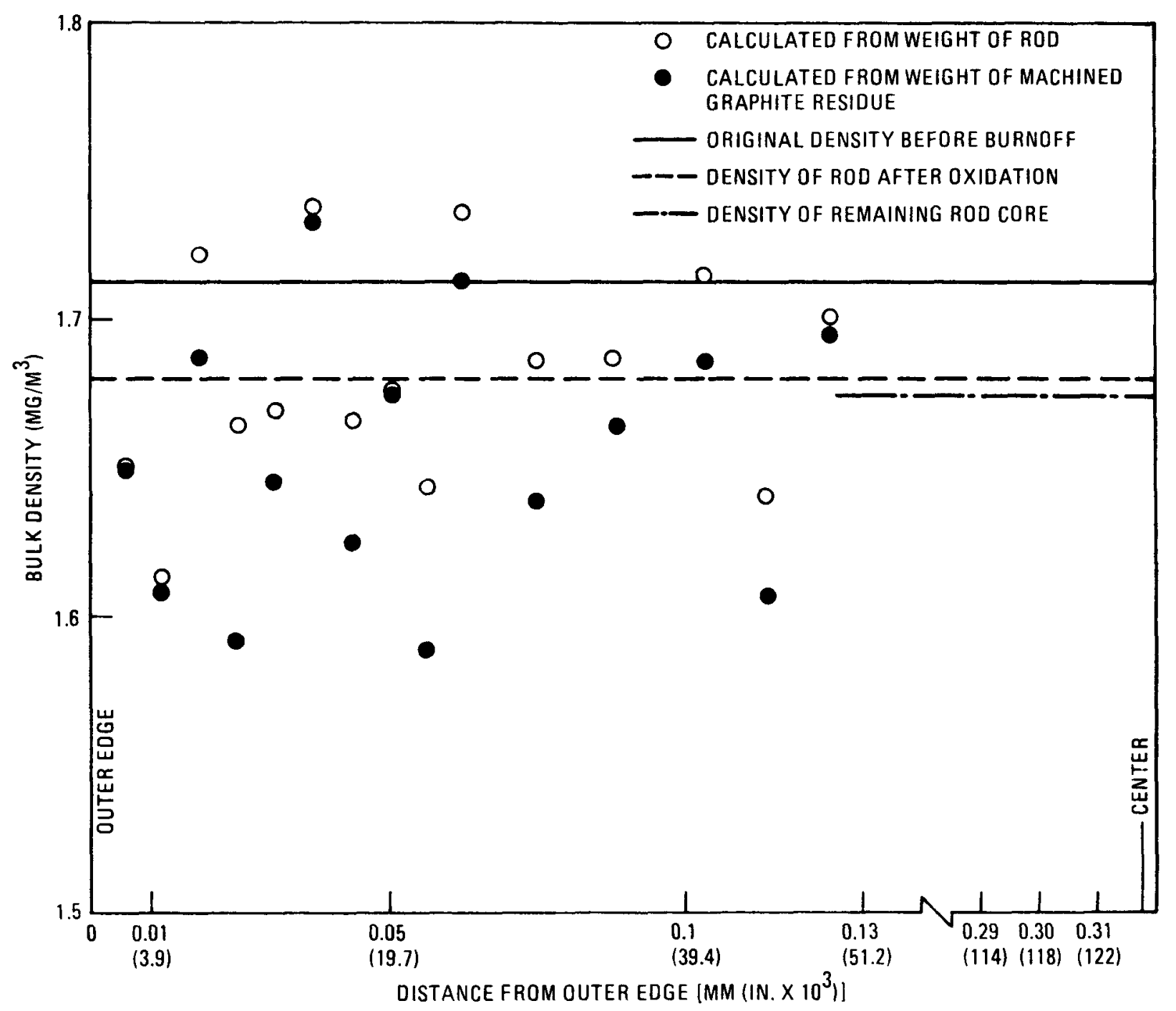

Fig. 16. Bulk density profile of $\mathrm{H}-451$ graphite (sample 6484-34-5B): quarter-1ength axial center specimen oxidized at $1273 \mathrm{~K}\left(1832^{\circ} \mathrm{F}\right)$ to $4.3 \%$ burnoff 


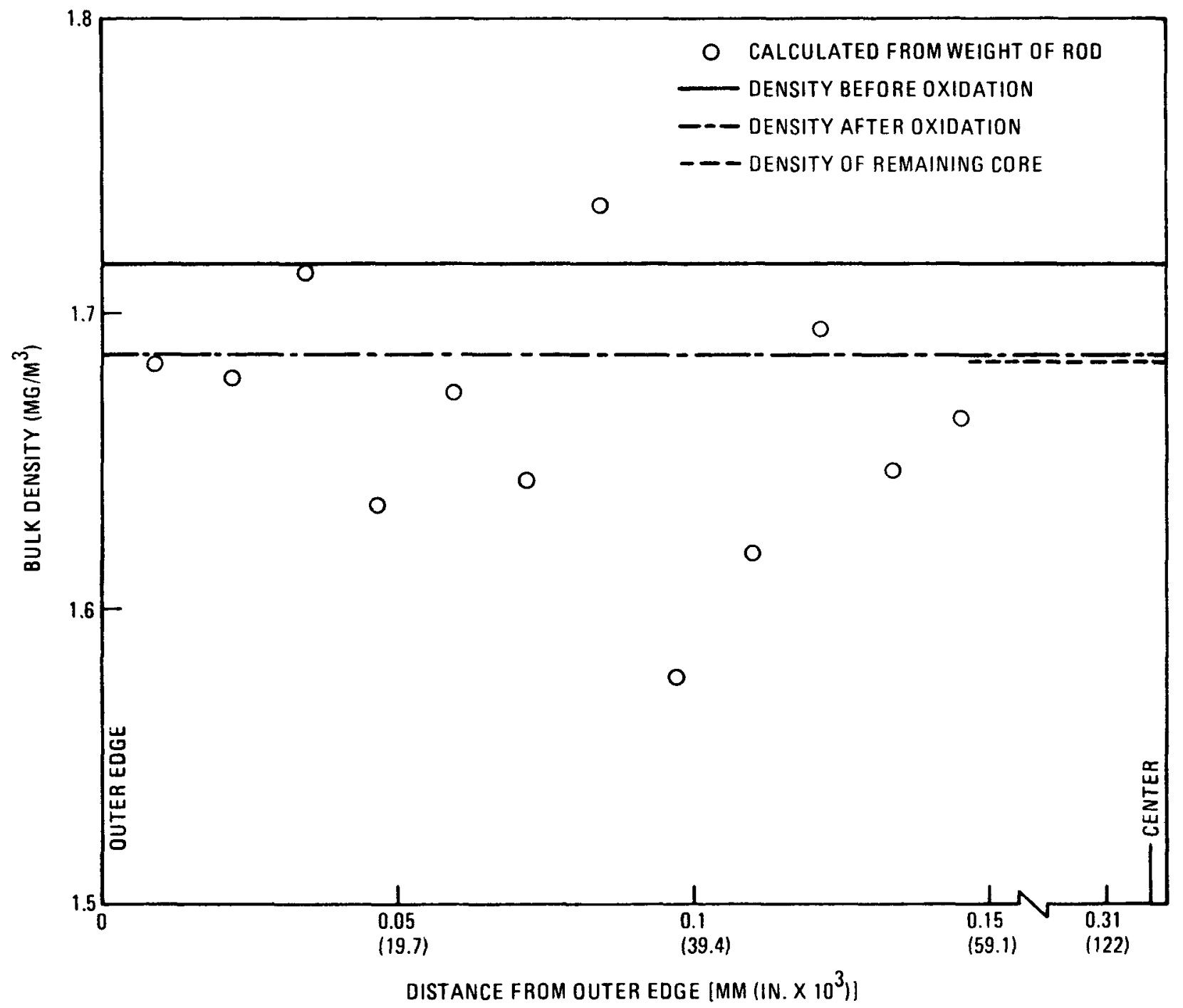

Fig. 17. Bulk density profile of H-451 graphite (sample 6484-34-5A-29B): quarter-1ength axial center specimen oxidized at $1273 \mathrm{~K}\left(1832^{\circ} \mathrm{F}\right)$ to $1.5 \%$ burnoff 
17 and in all cases confirmed the apparent density trends of the smaller increments taken near the outer edge of the specimens.

The oxidation profiles are uniform for all specimens oxidized at 1073 or $1273 \mathrm{~K}\left(1472^{\circ}\right.$ or $\left.1832^{\circ} \mathrm{F}\right)$. It was anticipated that some preferential oxidation on the outer surface of the samples would occur at $1273 \mathrm{~K}$ $\left(1832^{\circ} \mathrm{F}\right)$; $i . e .$, the final density profile along the radius after oxidation should increase from the outer edge toward the center. This type of gradient was observed in specimen 34-5B (see Fig. 16). In the other cases, as shown in Fig. 17, oxidation at $1273 \mathrm{~K}\left(1832^{\circ} \mathrm{F}\right)$ produced a uniform profile. It is concluded from the bulk density profile data that all UTS specimens were uniformly oxidized across the radius. 
4. CONCLUSIONS

The following conclusions have been reached:

1. The E and UTS of H-451 graphite were decreased by an average of $3.6 \%$ and $5.2 \%$ respectively, per percent burnoff for specimens oxidized at $1273 \mathrm{~K}\left(1832^{\circ} \mathrm{F}\right)$ and $5.2 \%$ UTS and $10.5 \% \mathrm{E}$ for specimens oxidized at $1073 \mathrm{~K}\left(1472^{\circ} \mathrm{F}\right)$. This conclusion is based on averaging data from specimens of all log locations, orientations, and burnoffs.

2. There was no significant reduction in UTS in center axial specimens oxidized to burnoffs of up to $1.9 \%$ at either 1073 or $1273 \mathrm{~K}$ $\left(1472^{\circ}\right.$ or $\left.1832^{\circ} \mathrm{F}\right)$ and no significant reduction in $E$ in the same specimens oxidized to burnoffs of up to $1.9 \%$ at $1273 \mathrm{~K}\left(1832^{\circ} \mathrm{F}\right)$. These results are of particular importance because the maximum volumetric burnoff in the HTGR fuel element blocks has been calculated to be $1 \%$.

3. The rate of reduction of UTS and $E$ for center axial specimens was greater at $1073 \mathrm{~K}\left(1472^{\circ} \mathrm{F}\right)$ than at $1273 \mathrm{~K}\left(1832^{\circ} \mathrm{F}\right)$. This difference is not important for design, because the volumetric burnoff of the fuel element blocks is calculated to be about $0.1 \%$ to $0.2 \%$ at $1073 \mathrm{~K}\left(1472^{\circ} \mathrm{F}\right)$.

4. In general, the reduction rate of $\mathrm{E}$ with burnoff was greater than that of UTS. The higher reduction rate of $E$ is important in design because a lower modulus decreases the secondary stresses, i.e., the thermal stresses resulting from gradients and differential irradiation-induced straln. 
5. The rate of reduction of UTS and $E$ for axial specimens oxidized at $1273 \mathrm{~K}\left(1832^{\circ} \mathrm{F}\right)$ was greater at the edge than at the center of a $10 \mathrm{~g}$. This does not impose a limitation in design, because the UTS of a fuel element block is always measured at the center of the log, where the minimum strength occurs. The UTS of the edge material of a $10 \mathrm{~g}$ oxidized up to $2 \%$ burnoff was never less than the UTS at the center samples for $0 \%$ to $2 \%$ burnoff.

6. In general, the reduction in UTS and $E$ for radial specimens was higher than that for axial specimens. The higher seismically induced stresses in an HTGR fuel element are in the radial direction, and thus this phenomenon could affect the design. However, the reduction in $E$ of the radial specimens was greater than the strength loss, and hence the overall effect on seismic performance will be negligible. 


\section{ACKNOWLEDGMENTS}

The authors wish to thank C. H. Richards, J. H. Whaley, and F. R. Hogan, Sr., for preparing the specimens and measuring the strength and modulus and G. B. Engle for his helpful comments and editing of the text. 
REFERENCES

1. Barse11, A. W., and M. B. Peroomian, "Consequences of Water Ingress Into the HTGR Primary Coolant," General Atomic Report GA-A13171, April 15, 1975.

2. Johnson, W. R., and G. B. Engle, "Properties of Unirradiated Fuel Element Graphites H-451 and TS-1240," ERDA Report GA-A13752, General Atomic, January 31, 1976.

3. Bevington, P. R., Data Reduction and Error Analysis for the Physical Sciences, McGraw-Hill, New York, 1969, pp. 84, 314.

4. Johnson, N. L., and F. C. Leone, Statistics and Experimental Design, v. 1, John Wiley and Sons, New York, 1964, p. 104.

5. Bevington, P. R., op. cit., p. 104.

6. Price, R. J., and H. R. W. Cobb, "Application of Weibull Statistical Theory to the Strength of Reactor Graphite," Gulf General Atomic Report GA-10257, August 6, 1970.

7. Price, R. J. "Statistical Study of the Strength of Near-Isotropic Graphite," ERDA Report GA-A13955, General Atomic, May 24, 1976. 
APPENDIX

TENSILE PROPERTIES OF H-451 GRAPHITE: LOG NO. 6484-34

(SPECIMEN DIAMETER $=6.4 \mathrm{MM}$, LENGTH $=23$ MM) 
CONTROLS

\begin{tabular}{|c|c|c|c|c|c|c|c|}
\hline $\begin{array}{l}\text { Specimen } \\
\text { Number }\end{array}$ & Orientation & Location & $\begin{array}{l}\text { Density } \\
\left(\mathrm{mg} / \mathrm{m}^{3}\right)\end{array}$ & $\begin{array}{l}\text { Young's } \\
\text { Modulus } \\
\text { (GPa) }\end{array}$ & $\begin{array}{c}\text { Permanent } \\
\text { Set } \\
(\%)\end{array}$ & $\begin{array}{c}\text { Fracture } \\
\text { Strain } \\
(\%)\end{array}$ & $\begin{array}{l}\text { Tensile } \\
\text { Strength } \\
\text { (MPa) }\end{array}$ \\
\hline $5651-23-5 A-1 A$ & Axial & QLC & 1.726 & 0.865 & 0.039 & 0.235 & 11.38 \\
\hline 1B & & & 1.721 & -- & -- & -- & 11.52 \\
\hline $5 \mathrm{~A}$ & & & 1.730 & 1.046 & 0.031 & 0.279 & 11.10 \\
\hline $5 B$ & & & - & -- & -- & - & 13.22 \\
\hline $16 \mathrm{~A}$ & & & 1.726 & 0.882 & 0.049 & 0.307 & 12.95 \\
\hline $16 \mathrm{~B}$ & & & -- & -- & -- & - & 10.83 \\
\hline $20 \mathrm{~A}$ & & & 1.724 & 1.250 & 0.022 & 0.228 & 13.20 \\
\hline 20B & & & -- & -- & - & -- & 13.07 \\
\hline $33 \mathrm{~A}$ & & & 1.726 & -- & - & - & 4.50 \\
\hline $33 \mathrm{~B}$ & & & -- & -- & - & - & 13.89 \\
\hline $37 \mathrm{~A}$ & & & - & -- & -- & -- & -- \\
\hline $37 \mathrm{~B}$ & & & - & -- & - & -- & - \\
\hline $11 \mathrm{~A}$ & & & 1.725 & 1.084 & 0.032 & 0.185 & 9.05 \\
\hline $11 \mathrm{~B}$ & & & 1.723 & -- & -- & -- & 16.85 \\
\hline $14 \mathrm{~A}$ & & & 1.714 & -- & - & -- & 13.96 \\
\hline $14 B$ & & & -- & -- & -- & -- & 12.10 \\
\hline $21 \mathrm{~A}$ & & & 1.732 & 1.168 & 0.038 & 0.326 & 15.11 \\
\hline $21 \mathrm{~B}$ & & & - & -- & -- & -- & 14.21 \\
\hline $24 \mathrm{~A}$ & & & 1.724 & 1.323 & 0.032 & 0.247 & 15.13 \\
\hline $24 B$ & & & - & -- & -- & - & 12.55 \\
\hline $26 \mathrm{~A}$ & & & 1.726 & 1.046 & 0.040 & 0.300 & 13.66 \\
\hline $26 \mathrm{~B}$ & 1 & 1 & -- & -- & - & - & 12.16 \\
\hline
\end{tabular}


OXIDIZED AT $1073 \mathrm{~K}\left(1472^{\circ} \mathrm{F}\right)$

\begin{tabular}{|c|c|c|c|c|c|c|c|c|c|}
\hline \multicolumn{2}{|c|}{$\begin{array}{c}\text { Specimen } \\
\text { Number }\end{array}$} & Orientation & Location & $\begin{array}{c}\text { Density } \\
\left(\mathrm{mg} / \mathrm{m}^{3}\right)\end{array}$ & $\begin{array}{l}\text { Young's } \\
\text { Modulus } \\
(\mathrm{GPa})\end{array}$ & $\begin{array}{c}\text { Permanent } \\
\text { Set } \\
(\%) \\
\end{array}$ & $\begin{array}{c}\text { Fracture } \\
\text { Strain } \\
(\%)\end{array}$ & $\begin{array}{l}\text { Tensile } \\
\text { Strength } \\
(\mathrm{MPa}) \\
\end{array}$ & $\begin{array}{c}\text { Burnoff } \\
(\%)\end{array}$ \\
\hline \multicolumn{2}{|c|}{$5651-23-5 A-2 A$} & \multirow[t]{20}{*}{ Axial } & \multirow[t]{20}{*}{ QLC } & 1.710 & -- & - & - & 11.6 & 0.17 \\
\hline & $2 \mathrm{~B}$ & & & 1.715 & -- & -- & -- & 14.0 & 0.17 \\
\hline & $13 \mathrm{~A}$ & & & 1.703 & \multicolumn{3}{|c|}{$\longrightarrow$ Bond failure $\longrightarrow$} & -- & 0.97 \\
\hline & $13 \mathrm{~B}$ & & & 1.698 & -- & -- & -- & 12.6 & 0.97 \\
\hline & $17 \mathrm{~A}$ & & & 1.697 & 7.29 & 0.03 & 0.29 & 14.0 & 0.36 \\
\hline & $17 \mathrm{~B}$ & & & 1.700 & 6.46 & 0.04 & 0.25 & 11.1 & 0.36 \\
\hline & $26 \mathrm{~A}$ & & & 1.698 & -- & -- & -- & 16.0 & 0.21 \\
\hline & $26 B$ & & & 1.690 & -- & -- & -- & 15.6 & 0.21 \\
\hline & $31 \mathrm{~A}$ & & & 1.685 & 7.21 & 0.04 & 0.30 & 13.9 & 1.37 \\
\hline 1 & $31 \mathrm{~B}$ & & & 1.685 & 6.21 & 0.03 & 0.28 & 13.0 & 1.37 \\
\hline \multicolumn{2}{|c|}{$5651-23-5 B-1 A$} & & & 1.703 & -- & -- & -- & 14.2 & 1.30 \\
\hline & $1 \mathrm{~B}$ & & & 1.677 & -- & -- & -- & 11.8 & 1.30 \\
\hline & $7 \mathrm{~A}$ & & & 1.702 & -- & - & -- & 11.7 & 0.27 \\
\hline & $7 \mathrm{~B}$ & & & 1.703 & -- & -- & -- & 11.4 & 0.27 \\
\hline & $9 \mathrm{~A}$ & & & 1.705 & 7.85 & 0.03 & 0.26 & 14.4 & 0.19 \\
\hline & $9 \mathrm{~B}$ & & & 1.710 & 7.05 & 0.04 & 0.31 & 14.6 & 0.19 \\
\hline & $28 \mathrm{~A}$ & & & 1.700 & 6.97 & 0.04 & 0.27 & 12.8 & 0.87 \\
\hline & $28 \mathrm{~B}$ & & & 1.698 & 6.97 & 0.05 & 0.32 & 13.4 & 0.87 \\
\hline & $33 \mathrm{~A}$ & & & 1.717 & - & -- & -- & 12.8 & 0.35 \\
\hline$i$ & $33 B$ & & & 1.705 & -- & -- & - & 13.5 & 0.35 \\
\hline
\end{tabular}


OXIDIZED AT $1073 \mathrm{~K}\left(1472^{\circ} \mathrm{F}\right)$

\begin{tabular}{|c|c|c|c|c|c|c|c|c|}
\hline $\begin{array}{c}\text { Specimen } \\
\text { Number }\end{array}$ & Orientation & Location & $\begin{array}{l}\text { Density } \\
\left(\mathrm{mg} / \mathrm{m}^{3}\right)\end{array}$ & $\begin{array}{c}\text { Young's } \\
\text { Modulus } \\
(\mathrm{GPa}) \\
\end{array}$ & $\begin{array}{c}\text { Permanent } \\
\text { Set } \\
(\%)\end{array}$ & $\begin{array}{c}\text { Fracture } \\
\text { Strain } \\
(\%)\end{array}$ & $\begin{array}{l}\text { Tensile } \\
\text { Strength } \\
\text { (MPa) }\end{array}$ & $\begin{array}{c}\text { Burnoff } \\
(\%)\end{array}$ \\
\hline $5651-23-5 A-3 A$ & Axial & QLC & 1.695 & 7.21 & 0.06 & 0.271 & 12.1 & 1.15 \\
\hline $3 B$ & & & 1.693 & 5.39 & 0.04 & 0.253 & 8.7 & 1.15 \\
\hline $6 \mathrm{~A}$ & & & 1.700 & 6.67 & 0.06 & 0.351 & 13.7 & 0.88 \\
\hline $6 B$ & & & 1.708 & 6.27 & 0.03 & 0.374 & 13.2 & 0.88 \\
\hline $18 \mathrm{~A}$ & & & 1.677 & -- & -- & -- & 11.7 & 1.60 \\
\hline $18 \mathrm{~B}$ & & & 1.678 & -- & -- & -- & 13.1 & 1.60 \\
\hline $21 \mathrm{~A}$ & & & 1.695 & 5.39 & 0.05 & 0.339 & 11.9 & 1.44 \\
\hline $21 B$ & & & 1.694 & 8.38 & 0.05 & 0.215 & 11.2 & 1.44 \\
\hline $23 \mathrm{~A}$ & & & 1.694 & 5.69 & 0.01 & 0.280 & 11.2 & 1.43 \\
\hline $23 B$ & & & 1.694 & 4.50 & 0.07 & 0.270 & 10.3 & 1.43 \\
\hline $36 \mathrm{~A}$ & & & 1.683 & -- & -- & - & 10.8 & 1.40 \\
\hline $36 \mathrm{~B}$ & & & 1.678 & -- & - & -- & 11.7 & 1.40 \\
\hline $5651-23-5 B-4 A$ & & & 1.699 & - & -- & -- & 13.2 & 0.92 \\
\hline $4 B$ & & & 1.698 & -- & -- & -- & 11.5 & 0.92 \\
\hline $15 \mathrm{~A}$ & & & 1.697 & -- & - & -- & 12.1 & 0.96 \\
\hline $15 B$ & & & 1.683 & -- & -- & -- & 12.8 & 0.96 \\
\hline $29 A$ & & & 1.690 & - & -- & -- & 13.6 & 1.34 \\
\hline $29 B$ & & & 1.694 & $\longleftarrow$ & Bond failu & 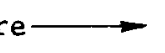 & -- & 1.34 \\
\hline $30 \mathrm{~A}$ & & & 1.683 & - & -- & -- & 10.8 & 1.28 \\
\hline $30 \mathrm{~B}$ & & & 1.675 & + & -Bond failu & $\longrightarrow$ & -- & 1.28 \\
\hline $32 \mathrm{~A}$ & & & 1.695 & -- & -- & -- & 12.7 & 0.86 \\
\hline $32 \mathrm{~B}$ & & & 1.700 & -- & -- & -- & 10.6 & 0.86 \\
\hline $34 \mathrm{~A}$ & & & 1.698 & -- & -- & -- & 13.5 & 1.01 \\
\hline $34 \mathrm{~B}$ & 1 & 1 & 1.703 & - & -- & -- & 12.3 & 1.01 \\
\hline
\end{tabular}


OXIDIZED AT $1073 \mathrm{~K}\left(1472^{\circ} \mathrm{F}\right)$

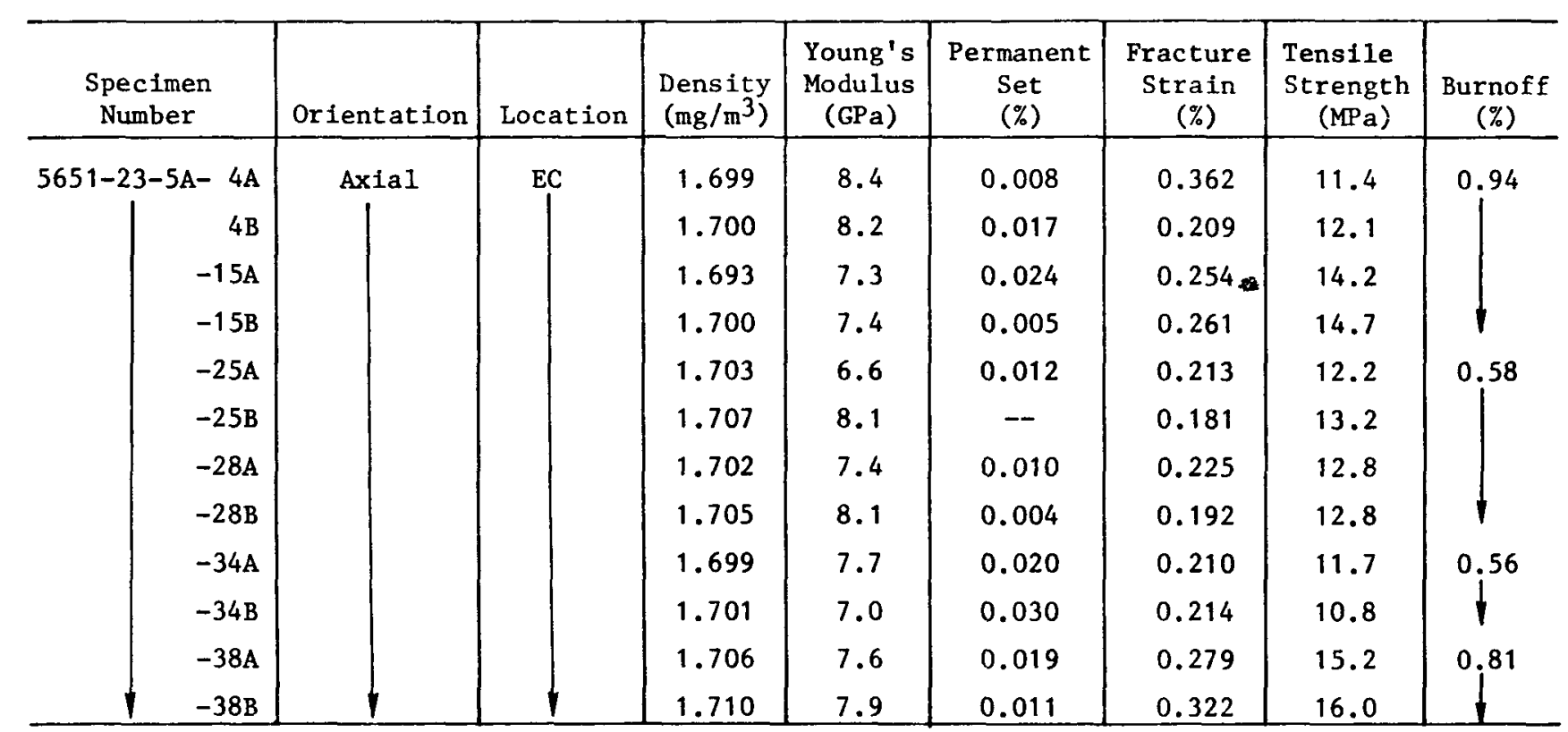


OXIDIZED AT $1273 \mathrm{~K}\left(1832^{\circ} \mathrm{F}\right)$

\begin{tabular}{|c|c|c|c|c|c|c|c|c|c|}
\hline \multicolumn{2}{|c|}{$\begin{array}{l}\text { Specimen } \\
\text { Number }\end{array}$} & Orientation & Location & $\begin{array}{r}\text { Density } \\
\left(\mathrm{mg} / \mathrm{m}^{3}\right)\end{array}$ & \begin{tabular}{|c|} 
Young's \\
Modulus \\
(GPa)
\end{tabular} & $\begin{array}{c}\text { Permanent } \\
\text { Set } \\
(\%)\end{array}$ & $\begin{array}{c}\text { Fracture } \\
\text { Strain } \\
(\%)\end{array}$ & $\begin{array}{l}\text { Tensile } \\
\text { Strength } \\
\text { (MPa) }\end{array}$ & $\begin{array}{c}\text { Burnoff } \\
(\%)\end{array}$ \\
\hline \multicolumn{2}{|c|}{$5651-23-5 A-8 A$} & Axial & QLC & 1.703 & 6.74 & 0.039 & 0.310 & 14.2 & 1.05 \\
\hline & $8 \mathrm{~B}$ & & & 1.697 & 7.56 & 0.039 & 0.208 & 13.2 & 1.05 \\
\hline & $14 \mathrm{~A}$ & & & 1.695 & - & -- & - & 14.1 & 1.20 \\
\hline & $14 \mathrm{~B}$ & & & 1.677 & \multicolumn{3}{|c|}{$\longrightarrow$ Bond failure $\longrightarrow$} & -- & 1.20 \\
\hline & $19 \mathrm{~A}$ & & & 1.685 & \multicolumn{3}{|c|}{$\longrightarrow$ Bond failure $\longrightarrow$} & -- & 1.30 \\
\hline & $19 \mathrm{~B}$ & & & 1.690 & -- & -- & -- & 15.0 & 1.30 \\
\hline & $32 \mathrm{~A}$ & & & 1.702 & 6.46 & 0.041 & 0.342 & 13.2 & 1.24 \\
\hline & $32 B$ & & & 1.701 & 7.21 & 0.044 & 0.236 & 11.5 & 1.24 \\
\hline & $35 \mathrm{~A}$ & & & 1.692 & $\longrightarrow$ & Bond failur & $\longrightarrow$ & -- & 1.01 \\
\hline 1 & $35 B$ & & & 1.693 & +-1 & Bond failur & - & -- & 1.01 \\
\hline \multicolumn{2}{|c|}{$5651-23-5 B-2 A$} & & & 1.689 & -- & -- & -- & 13.4 & 1.26 \\
\hline & $2 B$ & & & 1.697 & $\leftarrow$ & 3ond failur & $\longrightarrow$ & -- & 1.26 \\
\hline & $12 \mathrm{~A}$ & & & 1.709 & 8.16 & 0.032 & 0.277 & 14.5 & 1.28 \\
\hline & $12 B$ & & & 1.708 & 6.89 & 0.040 & 0.251 & 12.3 & 1.28 \\
\hline & $25 \mathrm{~A}$ & & & 1.701 & 7.29 & 0.014 & 0.290 & 14.6 & 0.99 \\
\hline & $25 B$ & & & 1.703 & 6.53 & 0.039 & 0.322 & 13.4 & 0.99 \\
\hline & $27 \mathrm{~A}$ & & & 1.696 & -- & -- & - & 11.1 & 1.23 \\
\hline & $27 \mathrm{~B}$ & & & 1.699 & -- & -- & -- & 14.4 & 1.23 \\
\hline & $31 \mathrm{~A}$ & & & 1.692 & -- & -- & -- & 12.8 & 1.03 \\
\hline 1 & $31 \mathrm{~B}$ & 1 & 1 & 1.699 & $\leftarrow$ & Bond failur & $\longrightarrow$ & -- & 1.03 \\
\hline
\end{tabular}


OXIDIZED AT $1273 \mathrm{~K}\left(1832^{\circ} \mathrm{F}\right)$

\begin{tabular}{|c|c|c|c|c|c|c|c|c|}
\hline $\begin{array}{l}\text { Specimen } \\
\text { Number }\end{array}$ & Orientation & Location & $\begin{array}{l}\text { Density } \\
\left(\mathrm{mg} / \mathrm{m}^{3}\right)\end{array}$ & $\begin{array}{l}\text { Young 's } \\
\text { Modulus } \\
\text { (GPa) }\end{array}$ & $\begin{array}{c}\text { Permanent } \\
\text { Set } \\
(\%)\end{array}$ & $\begin{array}{c}\text { Fracture } \\
\text { Strain } \\
(\%)\end{array}$ & $\begin{array}{l}\text { Tensile } \\
\text { Strength } \\
\quad(\mathrm{MPa})\end{array}$ & $\begin{array}{c}\text { Burnoff } \\
(\%)\end{array}$ \\
\hline $5651-23-5 \mathrm{~A}-10 \mathrm{~A}$ & Axial & QLC & 1.675 & 7.66 & 0.051 & 0.26 & 12.7 & 1.90 \\
\hline $10 \mathrm{~B}$ & & & 1.676 & 5.96 & 0.048 & 0.31 & 12.1 & 1.90 \\
\hline $12 \mathrm{~A}$ & & & 1.678 & -- & -- & -- & 10.1 & 1.83 \\
\hline $12 \mathrm{~B}$ & & & 1.679 & -- & -- & -- & 13.4 & 1.83 \\
\hline $22 \mathrm{~A}$ & & & 1.688 & -- & -- & - & 13.9 & 1.71 \\
\hline $22 \mathrm{~B}$ & & & 1.685 & -- & -- & -- & 11.9 & 1.71 \\
\hline $24 \mathrm{~A}$ & & & 1.683 & 6.33 & 0.050 & 0.25 & 10.3 & 1.80 \\
\hline $24 \mathrm{~B}$ & & & 1.686 & 8.05 & 0.049 & 0.20 & 10.5 & 1.80 \\
\hline $29 \mathrm{~A}$ & & & 1.686 & 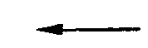 & Bond failu & $\longrightarrow$ & - & 1.55 \\
\hline $29 \mathrm{~B}$ & & & 1.687 & 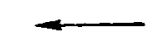 & Bond failu & $\longrightarrow$ & 12.7 & 1.55 \\
\hline $5651-23-5 B-8 A$ & & & 1.684 & 7.29 & 0.036 & 0.27 & 13.0 & 1.85 \\
\hline $8 B$ & & & 1.686 & 6.46 & 0.031 & 0.30 & 10.7 & 1.85 \\
\hline $13 \mathrm{~A}$ & & & 1.694 & 5.58 & 0.050 & 0.35 & 12.2 & 1.57 \\
\hline $13 B$ & & & 1.692 & 8.27 & 0.018 & 0.26 & 13.0 & 1.57 \\
\hline $18 \mathrm{~A}$ & & & 1.692 & -- & -- & - & 15.0 & 1.90 \\
\hline $18 \mathrm{~B}$ & & & 1.680 & $\leftarrow$ & Bond failu & - & - & 1.90 \\
\hline $22 \mathrm{~A}$ & & & 1.667 & $\leftarrow$ & Bond failu & - & -- & 1.79 \\
\hline $22 \mathrm{~B}$ & & & 1.679 & $\leftarrow$ & Bond failu & $\longrightarrow$ & -- & 1.79 \\
\hline $39 \mathrm{~A}$ & & & 1.685 & -- & - & -- & 13.6 & 1.47 \\
\hline $39 \mathrm{~B}$ & 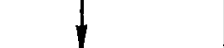 & $\downarrow$ & 1.690 & - & - & - & 14.5 & 1.47 \\
\hline
\end{tabular}


OXIDIZED AT $1273 \mathrm{~K}\left(1832^{\circ} \mathrm{F}\right)$

\begin{tabular}{|c|c|c|c|c|c|c|c|c|c|}
\hline $\begin{array}{c}\text { Specimen } \\
\text { Number }\end{array}$ & & Orientation & Location & $\begin{array}{r}\text { Density } \\
\left(\mathrm{mg} / \mathrm{m}^{3}\right) \\
\end{array}$ & $\begin{array}{l}\text { Young's } \\
\text { ModuIus } \\
\text { (GPa) }\end{array}$ & $\begin{array}{c}\text { Permanent } \\
\text { Set } \\
(\%)\end{array}$ & $\begin{array}{c}\text { Fracture } \\
\text { Strain } \\
(\%) \\
\end{array}$ & $\begin{array}{l}\text { Tensile } \\
\text { Strength } \\
\text { (MPa) }\end{array}$ & $\begin{array}{c}\text { Burnoff } \\
(\%)\end{array}$ \\
\hline $5651-23-5 \mathrm{~A}-$ & $7 \mathrm{~A}$ & Axial & QLC & 1.543 & - & - & -- & 11.8 & 6.68 \\
\hline & $7 \mathrm{~B}$ & & & 1.600 & -- & -- & - & 10.5 & 6.68 \\
\hline & $9 \mathrm{~A}$ & & & 1.593 & -- & -- & -- & 11.4 & 7.08 \\
\hline & $9 \mathrm{~B}$ & & & 1.597 & -- & -- & - & 11.1 & 7.08 \\
\hline & $11 \mathrm{~A}$ & & & -- & -- & -- & - & - & 7.43 \\
\hline & $11 \mathrm{~B}$ & & & -- & -- & - & -- & -- & 7.43 \\
\hline & $27 \mathrm{~A}$ & & & 1.611 & -- & -- & -- & 10.5 & 5.48 \\
\hline & $27 \mathrm{~B}$ & & & 1.584 & -- & -- & -- & 11.9 & 5.48 \\
\hline & $30 \mathrm{~A}$ & & & 1.609 & -- & -- & -- & 11.1 & 7.12 \\
\hline & $30 \mathrm{~B}$ & & & 1.598 & -- & -- & -- & 10.7 & 7.12 \\
\hline & $39 A$ & & & -- & -- & -- & -- & -- & 6.00 \\
\hline & $39 B$ & & & -- & -- & -- & - & - & 6.00 \\
\hline $5651-23-5 B-$ & $5 \mathrm{~A}$ & & & 1.594 & - & - & -- & 10.3 & 7.31 \\
\hline & $5 B$ & & & 1.589 & -- & - & - & 8.6 & 7.31 \\
\hline & $10 \mathrm{~A}$ & & & 1.589 & -- & - & -- & 8.6 & 6.82 \\
\hline & $10 \mathrm{~B}$ & & & 1.610 & -- & -- & - & 12.5 & 6.82 \\
\hline & $16 \mathrm{~A}$ & & & 1.613 & - & -- & -- & 12.2 & 6.48 \\
\hline & $16 \mathrm{~B}$ & & & 1.592 & -- & - & -- & 10.8 & 6.48 \\
\hline & $20 \mathrm{~A}$ & & & 1.593 & - & -- & - & 11.1 & 7.57 \\
\hline & $20 \mathrm{~B}$ & & & 1.586 & -- & -- & -- & 11.1 & 7.57 \\
\hline & $35 \mathrm{~A}$ & & & 1.575 & -- & -- & -- & 10.2 & 7.83 \\
\hline & $35 \mathrm{~B}$ & & & 1.604 & -- & -- & -- & 9.0 & 7.83 \\
\hline & $37 \mathrm{~A}$ & & & 1.638 & -- & -- & -- & 11.7 & 5.38 \\
\hline 1 & $37 \mathrm{~B}$ & 1 & 1 & 1.630 & -- & -- & -- & 8.0 & 5.38 \\
\hline
\end{tabular}


CONTROLS

\begin{tabular}{|c|c|c|c|c|c|c|c|}
\hline $\begin{array}{c}\text { Specimen } \\
\text { Number }\end{array}$ & Orientation & Location & $\begin{array}{l}\text { Density } \\
\left(\mathrm{mg} / \mathrm{m}^{3}\right)\end{array}$ & $\begin{array}{c}\text { Young's } \\
\text { Modulus } \\
(\mathrm{GPa})\end{array}$ & $\begin{array}{c}\text { Permanent } \\
\text { Set } \\
(\%)\end{array}$ & $\begin{array}{c}\text { Fracture } \\
\text { Strain } \\
(\%)\end{array}$ & $\begin{array}{l}\text { Tensile } \\
\text { Strength } \\
\text { (MPa) }\end{array}$ \\
\hline $5651-23-5 A-43 A$ & Radial & QLC & 1.724 & 6.82 & 0.041 & 0.253 & 11.58 \\
\hline $43 B$ & & & - & - & - & - & 13.64 \\
\hline $49 A$ & & & 1.722 & 6.74 & 0.049 & 0.358 & 14.49 \\
\hline $49 B$ & & & 1.720 & 6.33 & 0.049 & 0.290 & 11.97 \\
\hline $54 \mathrm{~A}$ & & & 1.722 & 6.39 & 0.043 & 0.280 & 11.37 \\
\hline $54 \mathrm{~B}$ & & & - & -- & -- & -- & 12.80 \\
\hline $60 \mathrm{~A}$ & & & 1.717 & 6.08 & 0.037 & 0.322 & 14.06 \\
\hline $60 \mathrm{~B}$ & & & 1.712 & - & -- & -- & 13.38 \\
\hline $64 \mathrm{~A}$ & & & 1.725 & -- & -- & -- & 10.97 \\
\hline $64 \mathrm{~B}$ & & & -- & -- & -- & -- & 11.27 \\
\hline $5651-23-5 B-40 A$ & & & 1.720 & 1.034 & 0.026 & 0.220 & 10.85 \\
\hline $40 \mathrm{~B}$ & & & 1.725 & -- & -- & -- & 11.47 \\
\hline $47 \mathrm{~A}$ & & & 1.717 & 1.0 & 0.031 & 0.246 & 12.41 \\
\hline $47 \mathrm{~B}$ & & & -- & -- & -- & - & 13.09 \\
\hline $52 \mathrm{~A}$ & & & 1.735 & -- & 0.044 & 0.270 & 13.29 \\
\hline $52 \mathrm{~B}$ & & & -- & -- & -- & - & 11.71 \\
\hline $57 \mathrm{~A}$ & & & 1.715 & - & -- & -- & 11.40 \\
\hline $57 \mathrm{~B}$ & & & -- & -- & -- & - & 12.39 \\
\hline $59 \mathrm{~A}$ & & & 1.713 & -- & 0.025 & 0.250 & 13.11 \\
\hline $59 \mathrm{~B}$ & 1 & 1 & -- & -- & - & -- & 9.18 \\
\hline
\end{tabular}


OXIDIZED AT $1073 \mathrm{~K}\left(1472^{\circ} \mathrm{F}\right)$

\begin{tabular}{|c|c|c|c|c|c|c|c|c|}
\hline $\begin{array}{l}\text { Specimen } \\
\text { Number }\end{array}$ & Orientation & Location & $\begin{array}{l}\text { Density } \\
\left(\mathrm{mg} / \mathrm{m}^{3}\right)\end{array}$ & $\begin{array}{l}\text { Young's } \\
\text { Modulus } \\
\text { (GPa) }\end{array}$ & $\begin{array}{c}\text { Permanent } \\
\text { Set } \\
(\%) \\
\end{array}$ & $\begin{array}{c}\text { Fracture } \\
\text { Strain } \\
(\%)\end{array}$ & $\begin{array}{c}\text { Tensile } \\
\text { Strength } \\
\text { (MPa) }\end{array}$ & $\begin{array}{c}\text { Burnoff } \\
(\%)\end{array}$ \\
\hline $5651-23-41 \mathrm{AA}$ & Radial & QLC & 1.556 & -- & -- & 0.127 & 5.9 & 9.514 \\
\hline$-41 \mathrm{AB}$ & & & 1.565 & -- & -- & 0.137 & 5.7 & 9.514 \\
\hline$-42 \mathrm{AA}$ & & & 1.566 & -- & -- & & 6.3 & 9.328 \\
\hline$-42 A B$ & & & 1.563 & 6.2 & 0.020 & 0.146 & 7.6 & 9.328 \\
\hline$-43 \mathrm{AA}$ & & & 1.556 & -- & - & 0.154 & 6.0 & 9.408 \\
\hline$-43 A B$ & & & 1.558 & -- & - & 0.155 & 6.7 & 9.408 \\
\hline$-44 \mathrm{AA}$ & & & 1.575 & -- & -- & 0.100 & 5.5 & 8.442 \\
\hline$-44 A B$ & & & 1.573 & -- & -- & 0.087 & 5.1 & 8.442 \\
\hline$-48 \mathrm{AA}$ & & & 1.554 & -- & - & 0.148 & 6.9 & 10.026 \\
\hline$-48 \mathrm{AB}$ & & & 1.542 & -- & -- & 0.124 & 6.2 & 10.026 \\
\hline$-52 \mathrm{AA}$ & & & 1.555 & -- & -- & 0.115 & 4.2 & 9.124 \\
\hline$-52 \mathrm{AB}$ & & & 1.562 & -- & -- & 0.149 & 7.1 & 9.124 \\
\hline$-54 \mathrm{AA}$ & & & 1.671 & -- & - & -- & 9.4 & 2.588 \\
\hline$-54 A B$ & & & 1.679 & 11.3 & 0.014 & 0.149 & 12.1 & 2.588 \\
\hline$-55 \mathrm{AA}$ & & & 1.659 & 9.2 & 0.020 & 0.168 & 11.2 & 3.337 \\
\hline$-55 \mathrm{AB}$ & & & 1.661 & 13.2 & 0.009 & 0.102 & 9.8 & 3.337 \\
\hline$-58 \mathrm{AA}$ & & & 1.670 & 10.2 & 0.013 & 0.126 & 9.7 & 2.488 \\
\hline$-58 B B$ & & & 1.673 & 12.7 & 0.010 & 0.132 & 11.5 & 2.488 \\
\hline$-62 \mathrm{AA}$ & & & 1.676 & -- & - & - & 10.4 & 2.709 \\
\hline$-62 A B$ & & & 1.656 & 10.9 & 0.005 & 0.111 & 10.4 & 2.709 \\
\hline$-63 A A$ & & & 1.665 & 9.7 & 0.016 & 0.105 & 8.2 & 2.905 \\
\hline$-63 A B$ & & & 1.665 & 10.9 & 0.010 & 0.139 & 11.0 & 2.905 \\
\hline$-65 A A$ & & & 1.662 & 10.5 & 0.010 & 0.138 & 11.1 & 2.955 \\
\hline$-65 \mathrm{AB}$ & $\downarrow$ & 1 & 1.667 & 11.7 & 0.010 & 0.140 & 11.8 & 2.955 \\
\hline
\end{tabular}


OXIDIZED AT $1273 \mathrm{~K}\left(1832^{\circ} \mathrm{F}\right)$

\begin{tabular}{|c|c|c|c|c|c|c|c|c|}
\hline $\begin{array}{l}\text { Specimen } \\
\text { Number }\end{array}$ & Orientation & Location & $\begin{array}{r}\text { Density } \\
\left(\mathrm{mg} / \mathrm{m}^{3}\right)\end{array}$ & $\begin{array}{l}\text { Young 's } \\
\text { Modulus } \\
\text { (GPa) }\end{array}$ & $\begin{array}{c}\text { Permanent } \\
\text { Set } \\
(\%)\end{array}$ & $\begin{array}{c}\text { Fracture } \\
\text { Strain } \\
(\%)\end{array}$ & $\begin{array}{l}\text { Tensile } \\
\text { Strength } \\
\quad(\mathrm{MPa})\end{array}$ & $\begin{array}{c}\text { Burnoff } \\
(\%)\end{array}$ \\
\hline $5651-23-5 A-40 A$ & Radial & QLC & 1.416 & & & & 2.82 & 19.5 \\
\hline $40 \mathrm{~B}$ & & & 1.377 & & & & 3.52 & 19.5 \\
\hline $50 \mathrm{~A}$ & & & 1.456 & & & & 1.83 & 15.7 \\
\hline $50 B$ & & & 1.445 & & & & 5.63 & 15.7 \\
\hline $56 \mathrm{~A}$ & & & 1.490 & & & & 6.03 & 13.4 \\
\hline $56 B$ & & & 1.464 & & & & 6.61 & 13.4 \\
\hline $59 \mathrm{~A}$ & & & 1.522 & & & & 7.87 & 10.6 \\
\hline $59 B$ & & & 1.536 & & & & 6.46 & 10.6 \\
\hline $61 \mathrm{~A}$ & & & 1.405 & & & & 5.63 & 18.9 \\
\hline $61 B$ & & & 1.368 & & & & 5.05 & 18.9 \\
\hline $63 A$ & & & 1.464 & & & & 6.76 & 13.5 \\
\hline $63 B$ & & & 1.483 & & & & 7.73 & 13.5 \\
\hline $5651-23-5 B-45 A$ & & & 1.457 & & & & 4.51 & 14.5 \\
\hline $45 B$ & & & 1.490 & & & & 5.92 & 14.5 \\
\hline $48 \mathrm{~A}$ & & & -- & & & & -- & 11.8 \\
\hline $48 B$ & & & -- & & & & -- & 11.8 \\
\hline $51 \mathrm{~A}$ & & & 1.397 & & & & 3.54 & 18.0 \\
\hline $51 \mathrm{~B}$ & & & 1.448 & & & & 4.66 & 18.0 \\
\hline $61 \mathrm{~A}$ & & & 1.444 & & & & 5.07 & 16.2 \\
\hline $61 \mathrm{~B}$ & & & 1.431 & & & & -- & 16.2 \\
\hline $65 A$ & & & 1.505 & & & & 8.98 & 13.5 \\
\hline $65 B$ & & & 1.486 & & & & 6.75 & 13.5 \\
\hline $67 \mathrm{~A}$ & . & & 1.534 & & & & 6.32 & 10.1 \\
\hline $67 \mathrm{~B}$ & 1 & 1 & 1.529 & & & & 8.29 & 10.1 \\
\hline
\end{tabular}


CONTROLS

\begin{tabular}{|c|c|c|c|c|c|c|c|}
\hline $\begin{array}{c}\text { Specimen } \\
\text { Number }\end{array}$ & Orientation & Location & $\begin{array}{l}\text { Density } \\
\left(\mathrm{mg} / \mathrm{m}^{3}\right)\end{array}$ & $\begin{array}{c}\text { Young's } \\
\text { Modulus } \\
(\mathrm{GPa})\end{array}$ & $\begin{array}{c}\text { Permanent } \\
\text { Set } \\
(\%)\end{array}$ & $\begin{array}{c}\text { Fracture } \\
\text { Strain } \\
(\%)\end{array}$ & \begin{tabular}{|c}
$\begin{array}{c}\text { Tensile } \\
\text { Strength } \\
\text { (MPa) }\end{array}$ \\
\end{tabular} \\
\hline $5651-24-5 A-101 A$ & Axial & QLE & -- & -- & -- & -- & 18.84 \\
\hline$-101 \mathrm{~B}$ & & & -- & -- & - & -- & 18.55 \\
\hline$-106 A$ & & & 1.759 & 9.12 & 0.025 & -- & - \\
\hline$-106 B$ & & & 1.758 & 7.56 & 0.036 & 0.370 & 19.26 \\
\hline$-111 A$ & & & -- & - & -- & -- & - \\
\hline$-111 \mathrm{~B}$ & & & - & -- & - & -- & 19.82 \\
\hline$-116 A$ & & & 1.724 & 6.74 & 0.025 & 0.291 & 13.82 \\
\hline$-116 B$ & & & 1.724 & 8.38 & 0.036 & 0.357 & 17.94 \\
\hline$-121 A$ & & & 1.761 & 7.56 & 0.047 & 0.416 & 21.35 \\
\hline$-121 B$ & & & 1.760 & 9.26 & 0.025 & -- & -- \\
\hline$-122 A$ & & & -- & -- & -- & -- & 17.97 \\
\hline$-122 B$ & & & -- & -- & -- & -- & 18.11 \\
\hline $5651-24-5 B-103 A$ & & & - & -- & -- & -- & -- \\
\hline$-103 B$ & & & -- & - & -- & - & -- \\
\hline$-104 \mathrm{~A}$ & & & 1.739 & 7.05 & 0.022 & -- & -- \\
\hline$-104 B$ & & & 1.740 & 8.49 & 0.029 & 0.371 & 19.92 \\
\hline$-112 \mathrm{~A}$ & & & 1.758 & 12.16 & 0.030 & - & -- \\
\hline$-112 B$ & & & 1.759 & 8.49 & 0.039 & 0.388 & 20.82 \\
\hline$-115 \mathrm{~A}$ & & & -- & - & -- & - & 20.11 \\
\hline$-115 B$ & & & -- & -- & -- & -- & -- \\
\hline$-117 A$ & & & -- & -- & -- & -- & 18.84 \\
\hline$-117 \mathrm{~B}$ & & & -- & -- & -- & -- & 18.86 \\
\hline$-123 A$ & & & 1.740 & 8.38 & 0.023 & -- & -- \\
\hline$-123 B$ & 1 & 1 & 1.746 & 9.54 & 0.029 & 0.343 & 19.84 \\
\hline
\end{tabular}


OXIDIZED AT $1073 \mathrm{~K}\left(1472^{\circ} \mathrm{F}\right)$

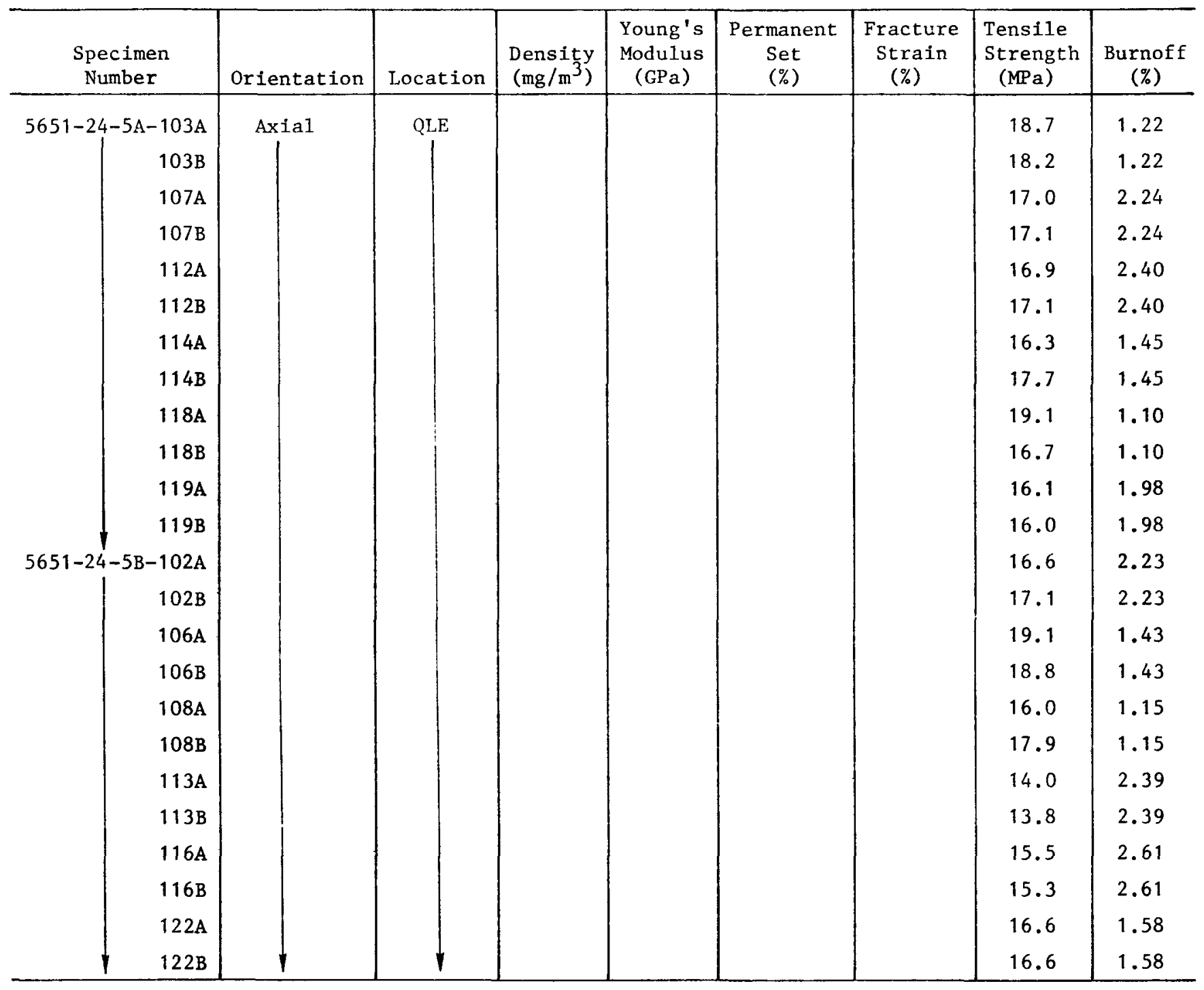


OXIDIZED AT $1273 \mathrm{~K}\left(1832^{\circ} \mathrm{F}\right)$

\begin{tabular}{|c|c|c|c|c|c|c|c|c|}
\hline $\begin{array}{l}\text { Specimen } \\
\text { Number }\end{array}$ & Orientation & Location & $\begin{array}{l}\text { Density } \\
\left(\mathrm{mg} / \mathrm{m}^{3}\right)\end{array}$ & $\begin{array}{l}\text { Young's } \\
\text { Modulus } \\
\text { (GPa) }\end{array}$ & $\begin{array}{c}\text { Permanent } \\
\text { Set } \\
(\%)\end{array}$ & $\begin{array}{c}\text { Fracture } \\
\text { Strain } \\
(\%)\end{array}$ & $\begin{array}{l}\text { Tensile } \\
\text { Strength } \\
\text { (MPa) }\end{array}$ & $\begin{array}{l}\text { Burnoff } \\
(\%)\end{array}$ \\
\hline $5651-24-5 A-102 A$ & Axial & QLE & 1.658 & 6.39 & 0.035 & 0.350 & 15.50 & 4.76 \\
\hline $102 \mathrm{~B}$ & & & 1.663 & 5.44 & 0.043 & 0.348 & 14.24 & 4.76 \\
\hline $109 \mathrm{~A}$ & & & 1.686 & 6.27 & 0.041 & 0.349 & 15.91 & 3.31 \\
\hline $109 \mathrm{~B}$ & & & 1.686 & 6.33 & 0.049 & 0.324 & 14.36 & 3.31 \\
\hline $110 \mathrm{~A}$ & & & -- & - & - & -- & 14.51 & 5.21 \\
\hline $110 \mathrm{~B}$ & & & -- & - & -- & -- & 14.93 & 5.21 \\
\hline $113 \mathrm{~A}$ & & & -- & - & -- & -- & -- & 4.86 \\
\hline 113B & & & -- & - & - & - & - & 4.86 \\
\hline $117 \mathrm{~A}$ & & & - & -- & -- & -- & 15.48 & 3.37 \\
\hline $117 \mathrm{~B}$ & & & -- & - & -- & -- & 15.48 & 3.37 \\
\hline $124 \mathrm{~A}$ & & & - & - & - & - & 15.46 & 4.70 \\
\hline $124 \mathrm{~B}$ & & & -- & - & -- & - & 13.62 & 4.70 \\
\hline $5651-24-5 B-101 A$ & & & -- & -- & - & -- & 15.92 & 3.30 \\
\hline $101 \mathrm{~B}$ & & & -- & - & -- & -- & 15.92 & 3.30 \\
\hline $105 \mathrm{~A}$ & & & -- & -- & -- & -- & -- & 4.6 \\
\hline $105 B$ & & & -- & -- & -- & - & -- & 4.6 \\
\hline $111 \mathrm{~A}$ & & & -- & - & -- & -- & 15.21 & 4.15 \\
\hline $111 \mathrm{~B}$ & & & - & -- & -- & -- & 15.38 & 4.15 \\
\hline $114 \mathrm{~A}$ & & & 1.656 & 6.67 & 0.022 & 0.365 & 16.33 & 4.16 \\
\hline $114 \mathrm{~B}$ & & & 1.659 & 5.30 & 0.041 & 0.280 & 11.57 & 4.16 \\
\hline $120 \mathrm{~A}$ & & & 1.661 & 7.13 & 0.032 & 0.290 & 14.09 & 4.59 \\
\hline $120 \mathrm{~B}$ & & & 1.645 & 6.97 & 0.032 & 0.350 & 15.80 & 4.59 \\
\hline $124 \mathrm{~A}$ & & & -- & -- & -- & -- & 13.69 & 4.34 \\
\hline $124 \mathrm{~B}$ & 1 & 1 & -- & -- & -- & -- & 14.70 & 4.34 \\
\hline
\end{tabular}


CONTROLS

\begin{tabular}{|c|c|c|c|c|c|c|c|}
\hline $\begin{array}{c}\text { Specimen } \\
\text { Number }\end{array}$ & Orientation & Location & $\begin{array}{r}\text { Density } \\
\left(\mathrm{mg} / \mathrm{m}^{3}\right)\end{array}$ & $\begin{array}{l}\text { Young's } \\
\text { Modulus } \\
(\mathrm{GPa})\end{array}$ & $\begin{array}{c}\text { Permanent } \\
\text { Set } \\
(\%)\end{array}$ & $\begin{array}{c}\text { Fracture } \\
\text { Strain } \\
(\%) \\
\end{array}$ & $\begin{array}{c}\text { Tensile } \\
\text { Strength } \\
\text { (MPa) }\end{array}$ \\
\hline $5651-24-5 A-128 A$ & Radial & QLE & 1.744 & 6.82 & 0.030 & 0.390 & 18.25 \\
\hline$-128 B$ & & & 1.728 & 8.49 & 0.029 & -- & - \\
\hline$-132 \mathrm{~A}$ & & & -- & -- & -- & -- & 17.10 \\
\hline$-132 B$ & & & - & -- & - & -- & -- \\
\hline$-134 \mathrm{~A}$ & & & 1.722 & 6.60 & 0.031 & 0.275 & 12.98 \\
\hline$-134 \mathrm{~B}$ & & & 1.744 & 8.62 & 0.031 & 0.307 & 15.96 \\
\hline$-136 A$ & & & - & -- & -- & -- & 6.80 \\
\hline$-136 \mathrm{~B}$ & & & - & -- & - & -- & 19.10 \\
\hline$-138 \mathrm{~A}$ & & & -- & -- & -- & -- & 12.31 \\
\hline$-138 \mathrm{~B}$ & & & -- & $\cdots$ & - & -- & 17.56 \\
\hline$-139 A$ & & & 1.747 & 8.16 & 0.038 & 0.359 & 17.88 \\
\hline$-139 B$ & & & 1.721 & 7.66 & 0.044 & 0.290 & 14.47 \\
\hline$-129 \mathrm{~A}$ & & & 1.744 & 8.16 & 0.012 & 0.276 & 15.44 \\
\hline$-129 B$ & & & 1.741 & -- & -- & -- & -- \\
\hline$-131 A$ & & & 1.736 & 8.27 & 0.026 & 0.299 & 15.39 \\
\hline$-131 B$ & & & 1.753 & 8.05 & 0.014 & 0.360 & 17.91 \\
\hline$-122 \mathrm{~A}$ & & & -- & -- & -- & -- & -- \\
\hline$-122 B$ & & & -- & -- & -- & -- & - \\
\hline$-136 A$ & & & - & -- & -- & -- & 14.73 \\
\hline$-136 B$ & & & -- & -- & - & - & 17.60 \\
\hline$-141 \mathrm{~A}$ & & & 1.725 & 7.56 & 0.030 & 0.310 & 15.15 \\
\hline$-141 \mathrm{~B}$ & & & 1.751 & 9.12 & 0.015 & 0.284 & 16.00 \\
\hline$-144 A$ & & & -- & - & -- & -- & 15.60 \\
\hline$-144 B$ & 1 & 1 & - & -- & -- & - & 17.14 \\
\hline
\end{tabular}


OXIDIZED AT $1073 \mathrm{~K}\left(1472^{\circ} \mathrm{F}\right)$

\begin{tabular}{|c|c|c|c|c|c|c|c|c|}
\hline $\begin{array}{c}\text { Specimen } \\
\text { Number }\end{array}$ & Orientation & Location & $\begin{array}{r}\text { Density } \\
\left(\mathrm{mg} / \mathrm{m}^{3}\right)\end{array}$ & $\begin{array}{l}\text { Young's } \\
\text { Modulus } \\
(\mathrm{GPa}) \\
\end{array}$ & $\begin{array}{c}\text { Permanent } \\
\text { Set } \\
(\%)\end{array}$ & $\begin{array}{c}\text { Fracture } \\
\text { Strain } \\
(\%) \\
\end{array}$ & $\begin{array}{l}\text { Tensile } \\
\text { Strength } \\
\text { (MPa) }\end{array}$ & $\begin{array}{c}\text { Burnoff } \\
(\%)\end{array}$ \\
\hline $5651-24-126 \mathrm{AA}$ & Radial & QLE & 1.519 & - & -- & 0.170 & 6.6 & 12.803 \\
\hline$-126 \mathrm{AB}$ & & & 1.512 & -- & -- & 0.179 & 6.6 & 12.803 \\
\hline$-126 \mathrm{BA}$ & & & 1.524 & 5.3 & 0.024 & 0.206 & 8.3 & 11.387 \\
\hline$-126 \mathrm{BB}$ & & & 1.533 & 6.1 & 0.020 & 0.139 & 7.2 & 11.387 \\
\hline$-127 \mathrm{AA}$ & & & 1.494 & -- & -- & 0.192 & 6.9 & 13.790 \\
\hline$-127 \mathrm{AB}$ & & & 1.499 & -- & -- & 0.164 & 6.0 & 13.790 \\
\hline$-132 \mathrm{AA}$ & & & 1.542 & 5.4 & 0.035 & 0.214 & 8.7 & 10.512 \\
\hline$-132 \mathrm{AB}$ & & & 1.565 & 5.9 & 0.025 & 0.186 & 8.7 & 10.512 \\
\hline$-133 \mathrm{AA}$ & & & 1.491 & -- & -- & 0.212 & 6.6 & 13.724 \\
\hline$-133 \mathrm{AB}$ & & & 1.500 & -- & -- & 0.194 & 6.3 & 13.724 \\
\hline$-134 \mathrm{AA}$ & & & 1.554 & 6.4 & 0.022 & 0.175 & 9.0 & 10.567 \\
\hline$-134 \mathrm{AB}$ & & & 1.558 & 4.9 & 0.034 & 0.213 & 8.3 & 10.567 \\
\hline$-137 \mathrm{AA}$ & & & 1.620 & 9.1 & 0.020 & 0.118 & 8.0 & 5.300 \\
\hline$-137 \mathrm{AB}$ & & & 4.887 & 10.3 & 0.013 & 0.167 & 12.2 & 5.300 \\
\hline$-137 \mathrm{BA}$ & & & 1.608 & 7.5 & 0.021 & 0.176 & 10.3 & 5.865 \\
\hline$-137 \mathrm{BB}$ & & & 1.624 & 8.3 & 0.013 & 0.189 & 11.9 & 5.865 \\
\hline$-138 \mathrm{AA}$ & & & 1.624 & 7.0 & 0.021 & 0.170 & 10.0 & 5.708 \\
\hline$-138 \mathrm{AB}$ & & & 1.607 & 7.0 & 0.025 & 0.176 & 9.6 & 5.708 \\
\hline$-141 \mathrm{AA}$ & & & 1.643 & 9.1 & 0.015 & 0.180 & 12.3 & 5.269 \\
\hline$-141 \mathrm{AB}$ & & & 1.614 & 9.9 & 0.015 & 0.142 & 10.1 & 5.269 \\
\hline$-142 \mathrm{AA}$ & & & 1.531 & -- & -- & & 9.7 & 5.751 \\
\hline$-142 \mathrm{AB}$ & & & 1.531 & 8.1 & 0.016 & 0.194 & 12.0 & 5.751 \\
\hline$-142 \mathrm{BA}$ & & & 1.537 & 8.1 & 0.010 & 0.190 & 11.6 & 4.954 \\
\hline$-142 \mathrm{BB}$ & 1 & 1 & 1.547 & 7.4 & 0.020 & 0.190 & 11.2 & 4.954 \\
\hline
\end{tabular}


OXIDIZED AT $1273 \mathrm{~K}\left(1872^{\circ} \mathrm{F}\right)$

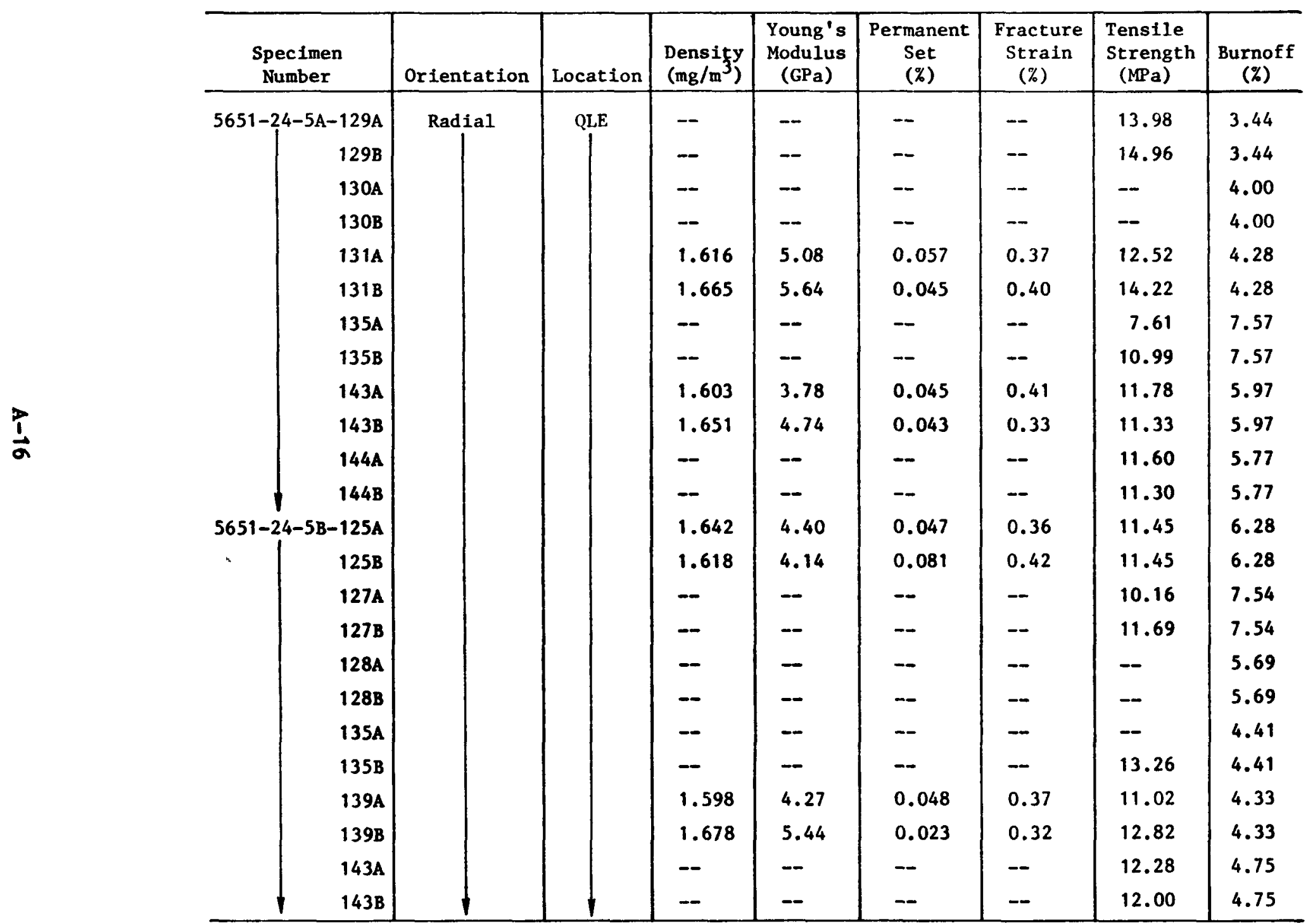

